\title{
Değerler Eğitimi Açısından Tek Parti Dönemi Âdâb-1 Muâşeret Kitapları
}

\author{
Kamil Çoştu \\ Dr., Bartın Üniversitesi, İslami İlimler Fakültesi, Din Eğitimi Anabilim Dalı \\ Dr., Bartin Universty, Faculty of Islamic Sciences, Department of Religious Education \\ Bartın, Turkey \\ kcostu@bartin.edu.tr \\ orcid.org/0000-0003-0467-7142
}

\section{Etiquette (Ādāb al-Muāsharah) Books of the One-Party Period in Terms of Values Education \\ Abstract}

The modernization concept that started in the last period of the Ottoman Empire was seen as a compulsory way to follow after the foundation of the Republic. Founded in 1923, CHP is the party that ruled the country alone between 1925-1945. Since one party was in the administration it is named as the "One-Party Period" between those years. Between the years 1925 and 1945 content of the modernization was seen in many fields such as political, socio-cultural, economics as being completely Europeanized, which was also reflected in the publications launched in the one-party period. One of the types of publications in which this understanding of modernization is seen as the most obvious is the works for etiquette (ādāb al-muāsharah). From the point of the quantity of these works, it is seen that the etiquette books published in the one-party period are relatively more than the Ottoman period. While 18 works were published in the late Ottoman period, 26 books were published in the one-party years. Within the scope of this research, 26 books with the title including the phrase "ādāb al-muāsharah" were examined. It was understood that the authors fully supported the socio-cultural changes that the political administration of the period wanted to make. Considering that these books were published at a time when religious and moral education was problematic; it is understood that it plays a clear mission and vision role in guiding the perception of the value of the society. There are differences in the use of the language of religion in publications before and after 1930. The language of religion which was seen as a mean of legitimizing the innovations brought by one-party management in the pre-1930s publications seems to have been used deliberatetly in the secular expressions, and the religious element, expression and way of living were belittled. In this article, firstly, the conceptual framework was explained and then the publications for the subject were examined in terms of changing the perception of value under the titles of personal, family, social and institutional etiquette. Although it was realized with modernization and European influence, it is seen that this issue had been important since the times of Sultan Mehmet the Conqueror and taught as a lesson in schools. Similar courses were included in the late Ottoman education and training curriculum. Looking at the publications launched in the one-party period in terms of authors, it is seen that some of compiled more than one work. In the publications, it was emphasized that personal care means modernization and that both men and women should mind. Otherwise, it is stated that it won't be valueable. This situation is valid not only for men but also for women. Another set of rules that men and women must follow is the way they conduct in social life. The reason why it is compulsory to follow these

Intihal Taraması/Plagiarism Detection: Bu makale intihal taramasından geçirildi/This paper was checked for plagiarism Geliş/Received: 31 Aralı//December 2019|Kabul/Accepted:01 Mart/March 2020 |Yayın/Published: 20 Mart/March 2020 Atıf/Cite as: Kamil Çoştu, "Değerler Eğitimi Açısından Tek Parti Dönemi Âdâb-1 Muâşeret Kitapları = Etiquette (Ādāb alMuāsharah) Books of the One-Party Period in Terms of Values Education", Eskiyeni 40 (Mart/March 2020), 129-153. https://doi.org/10.37697/eskiyeni.667810

Copyright () Anadolu Illahiyat Akademisi/Anatolian Theological Academy, 06050, Ankara, Turkey |www.anilakademi.com CC BY-NC 4.0 | This paper is licensed under a Creative Commons Attribution-NonCommercial License 
behaviors arises from the thought of ensuring the survival of the state. Otherwise, the common understanding was that the state will be shaken. For the reason that the only way the newly established state has chosen for itself is modernization. The survival of the state is mentioned in these works, which will be possible through the daily application of the European tradition. Looking at the works, it is seen that the understanding of family has changed quite a lot.

It was stated that the way family members address each other changes and some concepts are not suitable for use. It is no longer inconvenient to enter the houses with shoes, but various types of entertainment such as New Year's Eve enters into family life. A particular issue mentioned about the family is the understanding of gender equality. It was stated that the old times/administrations did not provide equality between men and women. The main issue that is expressed primarily for corporate prosperity is respect for managers. The second duty of a citizen who minds corporate success is to work hard and pay taxes. It is often mentioned that the future of the state depends on it. In some of the publications, it is seen that French, German, and Italian manners were taken as guides. While the French influence prevailed in the last period of the Ottoman Empire but at the beginning of the one-party years, it is understood from the publications that after 1930 the British rules of life gradually gained worth. In the publications, women and girls are mentioned as the most important social segment that must obey the rules. For this reason, it has been tried to express the values through women's, which are considered in the books of the etiquette. The types of clothing such as veils and burqa are expressed as out of age, and the types of clothing related to women's issues such as clothing-dressing and eating-drinking are mentioned. According to the published books of this period, it is quite natural for women to drink alcohol and dance with men. Even the woman should have a good knowledge of these. This indicates that the perception of value has changed and / or is desired to be changed. Many etiquette books were published after the one-party period. When these books are examined in general, it can be seen that they are parallel to the political understanding of the period. While publications of the last period of the Ottoman Empire is a signature of modernization from various perspectives, it is a way of becoming European in every aspect in the one-party period and making sense of value and direction. In fact, while the concept of "ādāb al-muāsharah" was an expression of modernization before 1945 , this situation started to lose its importance in the following years and became a conservative expression especially after 2000. As a result, we can express this: Many of the personal, domestic, social and institutional issues mentioned in the etiquette books published in the one-party period are important in terms of being a sign of the changing value perception of the period. In every period, there have been various types of publications which justify the innovations that political will wants to realize. In the single-party period, it is possible to see the etiquette books as a type of publication expressing the innovations that the constitutive will want to realize. Since the socio-cultural innovations realized by the constitutive will between 1925 and 1945 were directly or indirectly related to religious insights and practices, the works that were published in this period presented a new perception of value to the society.

\section{Keywords}

Religious Education, Values Education, Ādāb al-Muāsharah Books, Single Party, Value, Socio-Cultural Change, Innovation

\section{Öz}

\section{Değerler Eğitimi Açısından Tek Parti Dönemi Âdâb-1 Muâşeret Kitapları}

Osmanlı'nın son döneminde başlayan modernleşme anlayışı Cumhuriyet'in kuruluşu sonrasında takip edilmesi zorunlu yol olarak görülmüştür. 1923 yılında kurulan CHP, 1925-1945 arası yıllarda tek başına ülke yönetimini elinde bulunduran partidir. Bir partinin ülke yönetiminde söz sahibi olması sebebiyle mezkûr yıllar arası “Tek Parti Dönemi” olarak zikredilmektedir. 1925-1945 yılları arasında modernleşme; siyasî, sosyo-kültürel ve ekonomi gibi pek çok alanın içeriğinin tamamıyla Avrupalı- 
laşmak olarak görülmüş, bu durum tek parti döneminde neşredilen yayınlara yansımıştır. Bu modernleşme anlayışının en bariz görüldüğü yayın türlerinden biri “Âdâb-1 Muâşeret” yönelik eserlerdir. Bu eserlere nicelik açısından bakıldığında tek parti döneminde neşredilen âdâb-ı muâşeret kitaplarının son dönem Osmanlı'ya nispeten daha fazla olduğu görülmektedir. Son dönem Osmanlı'da on sekiz eser neşredilmişken, tek partili yıllarda yirmi altı kitap yayınlanmıştır. Bu araştırma kapsamında başlığında "âdâb-1 muâşeret" ifadesine yer verilen yirmi altı kitap incelenmiştir. Dönemin siyasî idaresinin yapmak istediği sosyo-kültürel değişiklikleri yazarların tamamen desteklediği anlaşılmıştır. Bu kitapların din ve ahlak eğitiminin sorunlu olduğu bir dönemde neşredildiği göz önünde bulundurulduğunda; toplumun değer algısının yönlendirilmesinde belirgin misyon ve vizyon görevi üstlendiği anlaşılmaktadır. 1930 öncesi ve sonrası yayınlarda din dilinin kullanımında farklılıklar bulunmaktadır. 1930 öncesi yayınlarda tek parti yönetiminin getirdiği yenilikleri meşrulaştırmanın bir aracı olarak görülen din dili, sonraki yıllarda bu anlayışa gerek duyulmayan, seküler ifadelerin bilinçli bir şekilde kullanıldığı, dinî unsur, ifade ve yaşayış şekillerinin küçümsendiği görülmektedir. Bu makalede öncelikle kavramsal çerçeve açıklanmış sonrasında ise, âdâb-1 muâşerete yönelik yayınlar kişisel, ailevî, toplumsal ve kurumsal görgü kuralları başlıkları altında değişen değer algısı açısından incelenmiştir. Her ne kadar âdâb-1 muâşeret modenleşme ve Avrupa etkisiyle gerçekleşmiş olsa da aslında Fatih Sultan Mehmet döneminden itibaren bu hususa önem verildiği, okullarda ders olarak okutulduğu görülmektedir. Son dönem Osmanlı eğitim-öğretim müfredatında da benzer dersler yer almıştır. Tek parti döneminde neşredilen âdâb-1 muâşerete yönelik yayınlara yazarları açısından bakıldı̆̆ında bazılarının birden fazla eser telif ettiği görülmektedir. Yayınlarda kişisel bakımın modernleşme demek olduğuna vurgu yapılarak hem erkeklerin hem de kadınların gerekli hassasiyetigöstermesi gerektiğine değinilmiştir. Aksi takdirde değer görmeyeceği ifade edilmiştir. Bu durum sadece erkekler için geçerli olmayıp, kadınları da kapsamaktadır. Kadın ve erkeğin uyması gereken bir diğer kurallar bütünü toplumsal hayata dair davranış şekilleri oluşturmaktadır. Bu davranış şekillerine uymanın zorunlu olmasının sebebi devletin bekasını sağlama düşüncesinden ileri gelmektedir. Aksi takdirde devletin bekası sarsılacağı anlayışı hâkimdir. Çünkü yeni kurulan devletin kendisine hedef seçtiği yegâne yol modernleşme ve çağdaşlaşmadır. Devletin bekası ise, Avrupa âdâb-1 muâşeretinin günlük hayatta tatbiki ile mümkün olacağı bu eserlerde zikredilmiştir. Eserlere bakıldığında, aile anlayışının oldukça değiştiği görülmektedir. Aile bireylerinin birbirine hitap şeklinin değiştiği, bazı kavramların kullanımının uygun olmadığ ifade edilmiştir. Artık evlere ayakkabı ile girmekte mahzur bulunmayıp, yılbaşı gibi çeşitli eğlence türlerinin aile hayatına girdiği görülmektedir. Aile ile ilgili olarak özellikle zikredilen bir husus ise, kadın-erkek eşitliği anlayışıdır. Eski devirler/yönetimler kadın-erkek eşitliğini sağlamadı̆̆ı ifade edilmiştir. Kurumsal âdâb-1 muâşerete yönelik öncelikle ifade edilen husus yöneticilere gösterilecek saygıdır. Kurumsal muâşerete önem gösteren bir vatandaşın ikinci görevi ise, çok çalısmak ve vergi vermektir. Devletin geleceğinin buna bağlı olduğu sıklıkla zikredilmiştir. Yayınların bir kısmında Fransız, bir kısmında ise, İngiliz, Alman ve İtalyan âdâb-1 muaşeretinin rehber alındığı görülmektedir. Osmanlı’nın son döneminde ve tek partili yılların başında Fransız etkisi hâkimken, 1930 sonrasında İngiliz yaşam kuralları giderek ağırlık kazandığıyayınlardan anlaşılmaktadır. Yayınlarda muâşeret kurallarına uyması gereken en önemli toplumsal kesim olarak kadınlar ve genç kızlar zikredilmiştir. Bu sebeple âdâb-ı muâşeret kitaplarında önemle ele alınan değerler kadınlar üzerinden dile getirilmeye çalışılmıştır. Çarşaf, peçe vb. giysi türleri çağdışı olarak ifade edilerek kadının giyim-kuşam, yeme-içme gibi hususları hakkındaki muâşeret şekillerine değinilmiştir. Bu dönem neşredilmiş âdâb-ı muâşeret kitaplarına göre kadının alkol kullanımı, erkeklerle dans etmesi oldukça doğal bir haldir. Hatta kadının bunlar hakkında çok iyi malumata sahip olması gerekir. Bu durum, değer algısının değiştiğini ve/veyahut değiştirilmek istendiğini göstermektedir. Tek parti döneminden sonra da pek çok âdâb-1 muâşeret kitabı neşredilmiştir. Bu kitaplara genel olarak bakıldığında, dönemin siyasî anlayışıyla paralellik arz ettiği görülmektedir. Osmanlı’nın son döneminde neşredilenler çeşitli açılardan modernleşmenin bir göstergesiyken, tek parti döneminde her açıdan Avrupalılaşmanın, değer algısı ve yönlendirmelerde bulunmanın bir yoludur. Hatta "Âdâb-1 
Muâşeret" kavramı 1945 öncesinde modernleşmenin bir ifade şekliyken, bu durum sonraki yıllarda önemini yitirmeye başlamış, özellikle 2000 sonrasında muhafazakâr bir ifade halini almıştır. Sonuç olarak şunu ifade etmemiz mümkündür: Tek parti döneminde neşredilen âdâb-1 muâşeret kitaplarında zikredilen kişisel, ailevi, toplumsal ve kurumsal pek çok husus dönemin değişen değer algısının bir göstergesi olması açısından önem arz etmektedir. Her dönemde siyasî iradenin gerçekleştirmek istediği yenilikleri meşru gösteren yayın çeşitleri ortaya çıkmıştır. Tek parti döneminde de âdâb-1 muâşeret" yayınları kurucu iradenin gerçekleştirmek istediği yenilikleri dile getiren bir yayın türü olarak görmek mümkündür. 1925-1945 yılları arasında kurucu iradenin gerçekleştirdiği sosyo-kültürel pek çok yenilik dinî anlayış ve uygulamalarla doğrudan veyahut dolaylı olarak ilişkili olması sebebiyle bu dönemde neşredilen âdâb-1 muâşerete yönelik eserler topluma yeni değer algisı sunmuştur.

\section{Anahtar Kelimeler}

Din Eğitimi, Değerler Eğitimi, Âdâb-1 Muâşeret Kitapları, Tek Parti, Değer, Sosyo-Kültürel Değişim, Yenilik

\section{Giriş}

İnsanoğlu, bulunduğu toplumun normlarına uygun hareket etme eğilimi gösterir. Toplumun kabul ettiği normlar ise; din, ırk, yaşanılan coğrafya-tarih, bilimsel gelişme veyahut başarı-yenilgilerle değişerek yenilenir. Bu anlamda son dönem Osmanlı veya erken dönem Cumhuriyet yıllarındaki norm değişikliğinin en önemli kök nedenlerinden biri, 17. yüzyılın sonlarında daha da belirginleşen mağlubiyetlerdir. Bu yenilgiler İbn Haldun'un dediği gibi toplumun; “... giyiminde-kuşamında, binitinde-binişinde, silahında, bunları yapış-kullanış yönteminde ve bunlara verilen biçimlerde, bunlardan başka konularda, başka durumlarda, benzeme çabasını bulursun" "1 anlayışının hâkimiyet kazanmasına sebebiyet vermiştir. Bu anlayış, dinin algılanışını, eğitimin yapısını ve sosyo-kültürel hayatın gidişatını derinden etkilemiştir. Avrupa'da meydana gelen din, eğitim, sosyal hayat ve yayıncılık ile irtibatlı gelişmeler Osmanlı topraklarında farklı türevleriyle er-geç gündeme gelmiştir. Mesela Tanzimat ilanı öncesinde ahlâkla ilgili yayın sayısı oldukça sınırlıyken, Avrupa'daki gelişmelere paralel olarak 19. yüzyıl sonunda bu alanda pek çok eser neşredilmiştir. ${ }^{2}$ Avrupâi tarzdaki âdâb-ı muâşeret kitaplarının yayımlanma serüveni de benzer özellik arz etmektedir. Tek parti dönemi olarak zikredilen 1925-1945 arası yıllarında meydana gelen değişiklikleri son dönem Osmanlı'da meydana gelen gelişme ve değişmelerden ayrı düşünmek veyahut değerlendirmek mümkün değildir.

Bu araştırmada tek parti olarak zikredilen 1925-1945 yılları arasında neşredilen âdâb-1 muâşeret kitaplarında yer alan değerler ve bunların eğitim materyali açısından kullanılışı ele alınmıştır. Mezkûr yıllar arasında örgün ve yaygın din eğitiminin giderek azalan

1 İbn Haldun, Mukaddime I, çev. Turan Dursun (Ankara: Onur Yayınları, 1977), 344.

2 Hatta 1910'lara gelindiğinde dünya çapında yarışmalar dahi yapılmıştır. Ahmed Naim, Ahlâk-ı İslâmiye Esasları (İstanbul: Amedî Matbaası, 1340-1342), 2; detaylı bilgi için lütfen bk. Kamil Çoştu, 1924-1949 Yılları Arasında Din Eğitimine Yönelik Yayınlanan Eserlerin Değerlendirilmesi (İstanbul: Marmara Üniversitesi, Sosyal Bilimler Enstitüsü, Din Eğitimi Bilim Dalı, Doktora Tezi, 2015), 219. Türk-İslam kültüründe ahlak kitabının çok fazla basılmamasının sebebini Aynî şu şekilde açıklamaktadır; "Eski âlimlerimiz başlı başına ahlâk kitabı yazmaya özenmemişlerdi. Onlar bu işi lüzumsuz görüyorlardı. Çünkü onların nazarında en yüksek bir ahlâk kitablmız vardı. Bu kitap Müslümanlar için Kur'ân-ı Kerim'di." Mehmed Ali Aynî, Türk Ahlâkçıları (İstanbul: Marifet Basımevi, 1939), 1/3. 
seyir takip etmesi hatta 1939-1949 yılları arasında örgün kurumların hiçbir seviyesinde bu eğitimin verilmemesi, ${ }^{3}$ toplumun din ve değerler eğitimine yönelik ihtiyacının giderilmesinde bu alanda neşredilmiş eserleri daha da önemli kılmaktadır.

1925-1945 yılları arasında hükümette olan parti CHP'dir. Cumhuriyet Türkiye'sinin en köklü partisi olan (kuruluşunda ismi “Halk Fırkası” olup, 1924’te “Cumhuriyet”, dördüncü büyük kongreden sonra da "Parti” ismini alan) CHP, 23 Ekim 1923’te kurulmuştur. 1923-1945 yılları arası Türkiye'sinde üç defa çok partili hayata geçme denemesi olmuşsa da, bu durum ancak, 1945'te gerçekleşebilmiştir. 1925-1945 arası ülke yönetiminin sadece CHP’nin söz sahibi olması bu yılların "Tek Parti” dönemi olarak adlandırılmasına sebebiyet vermiştir.

Tek parti döneminde neşredilmiş âdâb-ı muâşeret kitaplarını ele alan bu araştırmanın kavramsal çerçevesi ve hipotezi hakkında şunları söylemek mümkündür.

\section{Kavramsal ve Metodolojik Çerçeve}

Araştırma başlığında da görüldüğü üzere, bu çalışma “Âdâb-1 Muâşeret”, "Değerler Eğitimi” ve “Tek Parti” kavramları arasındaki ilişkiyi 1925-1945 yılları arasında neşredilmiş kitaplar baz alarak açıklamayı kendine problem edinmiştir. Bu sebeple, araştırma tek partili yıllarda neşredilen "âdâb-ı muâşeret" başlıklı yayınlarla sınırlanmıştır. Daha öncede ifade edildiği gibi mezkûr dönemde din eğitiminde yaşanılan sıkıntılar, toplumun değerlerini etkileyecek eserleri önemli kılmaktadır. Âdâb-ı muâşeret alanındaki eserler içerik analizi yapılarak ele alınmış olup, değişen değerlere vurgu yapılmıştır. Konu hakkında araştırmanın olmaması bu makalenin değerini artırmaktadır.

İnsanın manevî gelişimini besleyen araç olan değer, davranışları belirli kalıplara sokar. Bu durum ailede başlayıp okulda ve sosyal hayatta devam eden bir süreçtir. Bu süreçte insanoğlu ailesinden başlayarak toplumunun değerlerini keşfetmeyi ve uygulamayı öğrenir. ${ }^{5}$ Ailenin ve toplumun değerleri ise canlı bir varlık gibi değişmeyi kendisine şiar edinmiştir. Bu değişim içerisinde özellikle son yüzyılda din, bazı araştırmacılara göre değerlerin kaynağı olmaktan çımış veyahut en azından etkisini yitirmiştir. ${ }^{6}$ Bu hususta ilk değişen ise "Değer” kavramının kendisi olmuş, önem arz eden şeyler için bir üst 'isim' haline gelmiştir.7 Bu değerlerin öğretimi ise devletlerin bekası için önemli görülen eğitim konularından bir olarak değerlendirilmiştir.

Araştırma başlığımızda yer alan âdâb-ı muâşeret ise; "bir toplulukta uyulması gereken ve insanlar arasındaki davranışları düzenleyen nezaket, saygı ve görgü kuralları" şeklinde tanımlanmaktadır. ${ }^{8}$ Bazı yazarlar tarafından beynelmilel, ${ }^{9}$ kimi araştırmacı nezdinde ise topluma özgü kabul edilen âdâb-ı muâşeret, ${ }^{10} 1930$ sonrasında

\footnotetext{
Çoştu, 1924-1949 Yılları Arasında Din Eğitimine Yönelik Yayınlanan Eserlerin Değerlendirilmesi, 100-153.

Hakkı Uyar, Tek Parti Dönemi ve Cumhuriyet Halk Partisi (İstanbul: Boyut Kitapları, 1998), 67-80.

5 Ruth Elizabeth Deakin Crıck, “Farklı Kavramlar Mı, Madalyonun İki değişik Yüzü Mü?”, Değerler Eğitimi Uluslararast Konferansı (İstanbul: İstanbul İl Millî Eğitim Müdürlüğü, 2012), 196-199.

6 Recep Kaymakcan, “Gençlerin Dinî Değerlere Bakışı: Türkiye ve Avrupa Karş1laştırması”, Değerler Eğitimi Uluslararast Konferansı (İstanbul: İstanbul İl Millî Eğitim Müdürlüğü, 2012), 14.

7 Z. Şeyma Arslan - Fatma T. Yaşar, “Yükselen ‘Değer’ Kavramı Üzerine Eleştirel Bir Yaklaşım”, Değerler Eğitimi Merkezi Dergi 1 (Temmuz-Ağustos Eylül 2007), 8.

8 İlhan Ayverdi, Misalli Büyük Türkçe Sözlük: I(A-G) (İstanbul: Kubbealtı Yayınları, 2005), 24-27.

9 Sezai Tuncalı, Âdâb-ı Muâşeret (H.O. Basımevi, 1940), 1.

10 Nevin Meriç, Âdâb-ı Muâşeret: Osmanlı'da GündelikHayatın Değişimi (1894-1927) (İstanbul: Kapı Yayınları, 2007), XV.
} 
"Sosyete Kaideleri" olarak da ifade edilmiştir. ${ }^{11}$ Âdâb-1 muâşeret aslında alışkanlık haline gelmiş sıradan bedensel hareketlerin sergilenişi olup, arka planında değerler hiyerarşisi barındırmaktadır. ${ }^{12}$ Bu değerler hiyerarşisi kadın-erkek, genç-yaşlı, zengin-fakir herkese mekân tanımaksızın riayete mecbur bırakmaktadır. ${ }^{13}$ Çünkü insanoğlu maddî hayatın tesirlerinden azade kalamayan bir varlık olup, toplumsal kuralları öğrenme istidadına sahiptir. ${ }^{14}$ Öğreneceği bu görgü kuralları bir âdâb-1 muâşeret kitabında; "İnsanların birbirine, birinin diğerlerine, diğerlerinin birine karşı cemiyet münasebeti” olarak ifade edilmiş, ${ }^{15}$ bazı eserlerde cemiyette var olabilmek için bunun zarurî olduğuna vurgu yapılmıştır. ${ }^{16}$ Çünkü bu sayede insanoğlu cemiyete layık bir hüviyet edinebilmektedir. ${ }^{17}$ Son yüzyll âdâb-1 muâşeretinde; "bir vitrin sanatı doğurmuştur"18 şeklindeki tespitte de belirtildiği gibi görgü kuralları, maalesef araçtan ziyade amaç haline gelmiştir.

Osmanlı döneminde "Osmanlı Hanımefendisi veya Beyefendisi" olarak anılmak övünülecek bir halken, ${ }^{19} 20$. yüzyılın başında bu algılayış ilk önce devlet protokolündekiler ${ }^{20}$ akabinde genel halk kitlesi için değişmiştir. Bazı yayınlarda sonradan kabul edilen görgü ve protokol kurallarının Osmanlı'dan Avrupa ülkelerine gittiği ${ }^{21}$ millî an'ane ve törelerimize mugayir olmadığı, Türk ırkının bu hususta istidat sahibi olduğuna dikkat çekilmiştir. ${ }^{22}$ Tek parti döneminde neşredilen bazı yayınlarda ise âdâb-ı muâşerette geri kalmamızın suçlusu olarak padişahlar gösterilmiştir. ${ }^{23}$

Hâlbuki Fatih Sultan Mehmet'in fetih sonrası İstanbul'da inşa ettirdiği Enderun'unda okutulmakta olan derslerden biri “Teşrifat”tır. ${ }^{24}$ Aynı şekilde son dönem Osmanlı'da da Malumat-ı Nafia (Faydalı Bilgiler) ve İdare-i Beytiye (Ev İdaresi) gibi benzer içerikli âdâb-1 muâşerete dair dersler okutulmuştur. ${ }^{25}$ Bu durum, Osmanlı dönemine yönelik ortaya atılan iddianın yersiz olduğunun en bariz örneklerindendir.

19. yüzyıl Avrupa'sında âdâb-1 muâşerete yönelik pek çok yayının neşredilmesinin sebebi burjuva kültürünün yükselmesi ve yeni matbuat imkânlarının artmasıdır. ${ }^{26} \mathrm{Av}$ rupa'da bu alanda ilk neşredilen eser, 1530 yılında Desiderius Erasmus tarafindan kaleme

11 Derviş Okçabol, Meslek Terbiyesi: Muâşeret Teşkilat, Fiili Hizmet ve Zabıta Tarihi Ders Kitabı (Ankara: Ankara Polis Enstitüsü Neşriyatı, 1940), 7.

12 Seçil Deren, “Kültürel Batıllış̧ma”, Modern Türkiye'de SiyasîDüşünce: Modernleşme ve Batıcllk (İstanbul: İletişim Yayınları, 2002), 3/387.

13 Hüsnü Savaşçin, Âdâb-ı Muâşeret (Kayseri: Vilayet Matbaası, 1938), 2.

14 Okçabol, Meslek Terbiyesi: Muâşeret Teşkilat, Fiili Hizmet ve Zabıta Tarihi Ders Kitabı, 10.

15 Süheyla Muzaffer, Modern Âdâb-ı Muâşeret (İstanbul: İnkılap Yayınları, 1942), 7.

16 S. Arel, Halkve Talebeye Muaşeret Bilgileri (Ankara: İdeal Matbaa, 1939), 3.

17 Süheyla Muzaffer Dalkılıç, Talebeye Muaşeret Dersleri (İstanbul: Aydınlık Basımevi, 1939), 3.

18 Süheyla Muzaffer, Modern Adab-ı Muaşeret, 13.

19 Haluk Sena Arı - Kadriye Bayraktar, Dünden Bugüne Edep Geleneğimiz (İstanbul: Eşik Yayınları, 2011), 7.

20 Sezai Tuncalı, Âdâb-ı Muâşeret (H.O. Basımevi, 1940), 2-3.

21 Ayhan Şahin, Kamu İdarelerinde Protokol Kuralları (İstanbul: Yeniyüzyıl Yayınları, 2011), 2; Fatma Tunç Yaşar, Alafranga Halleri: Geç Osmanli'da Âdâb-ı Muâşeret (İstanbul: Küre Yayınları, 2016), 69-72.

22 Okçabol, Meslek Terbiyesi: Muâşeret Teşkilat, Fiili Hizmet ve Zabıta Tarihi Ders Kitabı, 8-9.

23 S. Muzaffer Dalkılıç, Talebeye Muașeret Dersleri, 6-7.

24 Ayhan Şahin, Kamu İdarelerinde Protokol Kuralları, 1-2.

25 Tunc Yasar, Fatma, “Geç Dönem Osmanlı Kız Mekteplerinde Fennî Ev İdaresi Eğitimi: Müfredat ve Ders Kitapları" Türkiyat Mecmuast-Journal of Turkology (Erişim Tarihi: 06.12.2019), 1-30; Haluk Sena Arı - Kadriye Bayraktar, Dünden Bugüne Edep Geleneğimiz (İstanbul: Eşik Yayınları, 2011), 49.

26 Fatma Tunç Yaşar, “Geç Dönem Osmanl ÂAâb-1 Muaşeret Literatürü”, Toplumsal Tarih Dergisi (Mart 2013), 52. 
alınan Çocuklar İçin Âdâb-ı Muâşeret (De Civilitate Morum Pverilium) adlı yayındır. ${ }^{27}$ Avrupa'da âdâb-1 muâşeret ile ilgili yayınlanmış en önemli yayın, ise Norbert Elias tarafindan 1939'da kaleme alınan Uygarlı Süreci adlı eserdir. ${ }^{28}$ Bu eserde yazar, Avrupa muâşeretinin geçirdiği safhalar hakkında malumatlar vermektedir. İslam kültüründe âdâb-ı muâşeret alanında neşredilmiş yayınlara bakıldığında, İslam âlimlerince bu alanda ilk eserlerin VIII. yüzyılda kaleme alınan İbn Kuteybe'nin Edebü'l-Kâtib, Hâris b. Esed el-Muhâsibînnin Âdâbü’n-Nüfûs, İbnü'l-Mukaffa'nın el-Edebü'l-Kebir ve el-Edebü's-Sağir adl1 eserler olduğu görülmektedir. ${ }^{29}$

Osmanlı'da âdâb-1 muâş̧erete dair eser az da olsa bulunmakla birlikte, var olan yayınlarda genel olarak saray teşrifat ve törenleri konu edilmektedir. Bunların en eski ve önemlilerinden biri Tevkiî̂ Abdurrahman Paşa tarafından 1676 'da kaleme alınmıştır. ${ }^{30}$ Son dönem Osmanlı'da bu alandaki neşriyatçıllk özellikle 1800'lerin sonlarında neşvü nemâ bulmuştur. 1889 yılından 1918'e kadar âdâb-1 muâşerete dair 13 kitap neşredilmiştir. ${ }^{31}$ Son dönem Osmanlı'da neşredilen yayınlar ile Cumhuriyet sonrası muâşeret kitapları bazı açılardan benzeşirken, kimi yönleriyle ayrışmaktadır. Bu hususları kısaca şu şekilde belirtmek mümkündür:

Her iki dönemde neşredilen eserlerin temel değerleri Batı âdâb-1 muâşeretine dayanmakta olup, bu durum bazı yayınların kapaklarına yansımıştır. ${ }^{32}$ Tek parti dönemi âdâb-ı muâşeret yayınları niceliksel açıdan Cumhuriyet öncesine nispeten ciddi artış göstermiştir. ${ }^{33}$ Son dönem Osmanlı'da âdâb-ı muâşeret kitaplarının muhatap kitlesi asker, bürokrat veya en azından il merkezlerinde yaşamını sürdüren kişilerken, tek parti döneminde tüm ülke vatandaşlarına hitap edilmektedir. ${ }^{34}$ Cumhuriyet öncesi muâşeret kitaplarında, Avrupa etkisi karşısında alınacak tavır ve buna karşılık yapılması gerekenler ile görgü kuralları dinî ve geleneksel referanslarla dile getirilirken, bu anlayışın özellikle 1930 sonrası yıllarda terkedildiği görülmektedir. Cumhuriyet öncesinde muâşeret kitaplarında Fransa örnekliği hâkimken, 1930 sonrasında İngiltere'nin bu hâkimiyeti ele geçirdiği görülmektedir. ${ }^{35}$ Osmanlı döneminde neşredilmiş bu kapsamdaki eserlerin bir kısmında âdâb-1 muâşeret yerine teşrifat, merasim, hüsn-i ülfet, nezaket, âdâb-1 umumiye vb. Arapçadan dilimize geçmiş terkipler kullanılırken, ${ }^{36}$ tek parti döneminde millileşmenin etkisiyle "görgü" vb. kavramların da yer aldığı görülmektedir.

27 Jacques Revel, “Adabı Muaşeretten Yararlanma Yolları”, Özel Hayatın Tarihi: 3 (İstanbul: YKY Yayınları, 2007), 187.

28 Norbert Elias, Uygarlk Süreci (çev. Ender Ateşman, İstanbul: İletişim Yayınları, 2017).

29 Mustafa Çağrıc1, "Edep”, DİA (İstanbul: Türkiye Diyanet Vakfı Yayınları, 1994), 10/413.

30 Herhangi bir nüshası bulunmayan kanunnameye 1331 yılında Millî Tetebbular Mecmuası, Sayı II, 497544’te yer verilmiştir. Sadık Müfit Bilge, Osmanlı Devleti’nde Teşrifat ve Törenler: Tevkiî Abdurrahman Paşa Kânun-Nâmesi (İstanbul: Kitabevi Yayınları, 2011), 1-45.

31 Yaşar, Geç Dönem Osmanll Âdâb-ı Muaşeret Literatürü, 53-54.

32 Ahmed Midhat Efendi, Avrupa Adab-ı Muașereti Yahud Alafranga (İstanbul: 1312); Comtessso de Magalon, Rehber-i Muaşeret: Avrupa Adab-ı Muaşereti, çev. Ahmed Cevad (ìstanbul: Artin Asaduryan ve Mahdumları Matbaas1, 1328/1912).

33 Tülin Ural, "Tek Parti Döneminde Basılmış Adab-1 Muaşeret Kitapları", Müteferrika: Kitabiyat Dergisi 33 (Yaz 2008), 244.

34 Nevin Meriç, Âdâb-ı Muâșeret: Osmanlida Gündelik Hayatın Değişimi (1894-1927) (ìstanbul: Kapı Yayınları, 2007), XIX, 521; Ural, Tek Parti Döneminde Baslmış Adab-ı Muaşeret Kitapları, 245-249, 255.

35 Yaşar, Geç Dönem Osmanl l̂Aâb-ı Muaşeret Literatürü, 55-56.

36 Yaşar, Alafranga Halleri: Geç Osmanlı'da Âdâb-1 Muâşeret, 46. 
Bu araştırma kapsamına sadece kitap başlığında "âdâb-ı muâşeret" kavramlarını kullanan eserler dâhil edilmiştir. Dönem içinde yazılan âdâb-1 muâşeret kitapları bunlarla sınırlı değildir. Kitap başlığında bu ifadeler yer almayan çeşitli görgü ve nezaket eserleri de neşredilmiştir. ${ }^{37}$ Örneğin Gottfried Andreas tarafından kaleme alınan Görgü adlı eser, bu tür özellikteki çeviri eser olup araştırmaya dâhil edilmemiştir. ${ }^{38}$ Araştırma kapsamında yirmi altı eser değerlendirilmiş olup, 1925 öncesi $^{39}$ ve 1945 sonrasında da ${ }^{40}$ bu alanda pek çok âdâb-ı muâşeret kitabı neşredilmiştir.

Tek parti döneminde pek çok hukukî düzenleme yapılmış olup, bunların bir kısmı âdâb-1 muâşerete yöneliktir. 9 Ocak 1927'de 4611 sayılı Heyet-i Vekile (Bakanlar Kurulu) Kararnamesi ile Türk protokolünün yükümlülüğünün Hariciye Vekilliği'ne (Dişişleri Bakanlığı Protokol Genel Müdürlüğ̈̈’ne) verilmesi, ${ }^{41}$ yabancı devletlerde bulunan elçilerimizin, katıldıkları davetlerde mahalli protokole riayetleri hususunda uyarılması bu duruma örnektir. ${ }^{42}$

Tek parti döneminde yapılan pek çok sosyo-kültürel değişikliğin kaynağında din ve değerler yer almaktadır. ${ }^{43}$ Mesela Türk Dili alanında yapılan çalışmalara din dilinin

37 Bu tür eserlerden bazıları şunlardır: Ademoğlu, Hayatta Muvaffak Olmak İçin Bir Genç Kızın Bileceği Şeyler (İstanbul: Tefeyyüz Kitaphanesi, 1932); Ali Remzi, Hayat-l İçtimaiye Hakkında, Harb Akademisi 1927-1928 (İstanbul: Harb Akademisi Kumandanlı̆̆ı Matbaası, 1928); Ali Vahit, Terbiye Dersleri (Ankara: Köy Hocası Matbaası, 1930); İsmail Hakkı Baltacıoğlu ve arkadaşları, Çocuk Hikâyeleri (Sebat Basımevi, 1939); Zeki Seren, Sihhat, Terbiye ve Giyim Hakkinda Umumi Prensip ve Adetler (İstanbul: Kanaat Kitabevi, 1940); S. Arel, Genç Kız ve Kadınlarımızın Cemiyette Seçecekleri Muhtelif Mesleklere Göre Kendilerinde Bulunması Lâzım Gelen Vasıflar (Ankara: İdeal Matbaası, 1939). Tek Parti döneminde CHP Halkevleri tarafından yayımlanan benzer içerikli bazı yayınlar şunlardır: Mustafa Reşit Tarakçıoğlu, Milli Terbiye ve Hedefleri (CHP İzmir Halkevi Yayınlarından) (izmir: Cumhuriyet Matbaası, 1949); Sabiha Yazgan, Çocuk Terbiyesi, CHP Aydın Halkevi (isstanbul: Ticaret Basımevi, 1935); Seyfi Kurtbek, Modern Yaşayış̧ Bilgileri (ìstanbul: Maarif Kitaphanesi, 1939); B. Malik - Hilmi A. Malik, Annelerin Kızlarına Öğütleri (Ankara: Ankara Halkevi, Hâkimiyeti Milliye Matbaası, 1933); Hıfzı Veldet, Evlenme ve Boşanma, CHP Genel Sekreterliği Konferansl (Ankara: Cezaevi Matbaası, 1938); Süheyla Altunç, Ev Idaresi (Devlet Basımevi, 1936).

38 Gottfried Andreas, Görgü, çev. Turan Aziz Beler (ìstanbul: Cumhuriyet Matbaası, 1943), 1-378.

39 Bu yayınlardan birkaçı şunlardır: Resulzade Hüseyin Hüsnü, Nezaket ve Usûl-i Muâşeret: Kavâi id-i Âdâb (İstanbul: Karabet ve Kasbar Matbaası, 1306/1889); Çençenzade Hakkı Antakyalı, Zarâfet, Kasbar Matbaası (Istanbul: 1890/1307); Ahmed Midhat Efendi, Avrupa Âdâb-ı Muâşereti Yahud Alafranga (istanbul, ikkdam Matbaası, 1312/1894); Amasyalı İbrahim Edhem, Rehber-i Müsafirin ve Âdâb-ı Muâsseret (istanbul: Kasbar Matbaası, 1316/1898).).

40 Bu tür yayınlardan bazıları şunlardır: Abdülfettah Ebu Gudde, Hayatın İçinden Âdâb ve Nezaket, çev: Osman Arpaçukuru (İstanbul: İlke Yayınları, 2002); Abdülkadir Halit, Âdâb-ı Muâşeret (İstanbul: Rehber Yayınları, 2006); Burhan Bozgeyik, Güzel Ahlak ve Âdâb-ı Muâşeret (İstanbul: Tuğra Neşriyat, 2015); Cemil Bürge, Çocuklara ve Gençlere Muâşeret Kaideleri (Aka, 1961); Emine Yüter, Görgü ve Nezaket Kuralları (isstanbul: Papatya Yayınları, 2003); Hasan Deniz, En Yeni Muâsşeret Kaideleri (İstanbul: Anten Yayınevi, 1961); Hava Kuvvetlerinde Muaşeret (Ankara: Hava Kuvvetleri Basımevi, 1967); Teslime Akkuş, Harun Özçelik, Hadisler'de Âdâb-ı Muaşeret (Erzurum, 2005); Halil Atalay, Âdâp Kuralları Ansiklopedisi (Konya; Ribat Yayınları, 2000).

41 Erdoğan Öznal, Protokol Görgü - Nezaket Kuralları (Ankara: Genelkurmay Başkanlığı Yayınları, 1992), 1 .

42 Başbakanlk Cumhuriyet Arşivi (BCA), Fon Kodu:30.18.1.1 Sayı:3025 Dosya:233-18 Yer No:17.84.19. Tarih:17/1/1926.

43 Kemal İnal, “Türkiye'de Geçmişten Günümüze Din Politikaları ve Eğitime Etkileri”, Değerler Eğitimi Merkezi Dergi 2 (2007), 15. 
dönüştürülmesi de eklenerek; Türkçe hutbe, Kur'ân-1 Kerim, ${ }^{44}$ mersiye, ${ }^{45}$ ezan $^{46}$ ve tekbir ${ }^{47}$ vb.'lerinde yeni uygulamalara gidilmiştir. Bununla birlikte, tekkelerin kapatılması, Latin alfabenin kabul edilmesi, medreselerin ilgası, sarık ve cübbelerin sadece din görevlilerince giyilmesi gibi yenilikleri Cumhuriyet'in ilanından on yıl önce İctihad Mecmuasi'ında savunan Dr. Abdullah Cevdet, tek parti döneminde zihniyet değişiminin sağlanamadığını iddia ederek görüşlerini şu şekilde ifade etmiştir:

Serpuş değiştirmeyi, kadınların yüzü örtülü çıkmaya mecbur tutulmamaları gibi şeyleri asrilik hatimesi addetmek bizden uzaktır. Biz serpuştan ziyade serlerin değişmesini istedik... Başımızda şapka, heykellerin başına takılan şapkalar gibi kaldıktan sonra ne işe yarar? Biz bununla mı mücadeleye hitam verilmek lazım geldiğine ve asriliğin fethedilmiş olduğuna hükmedeceğiz? İstanbul'da günde iki yüz kilo dudak boyası sarf olunuyormuş. Bu kadınlık haysiyetinin protesto edeceği bir şey değil midir?.. Analık ve ev hanımlı̆̆ hor görülüyor. Babalık ve ev efendiliği cazip görülmüyor. Böyle devirde ve böyle diyarda halis ve tam bir vatandaşın vazifesi nasıl bitmiş sayılabilir? ${ }^{48}$

Bu tür bakış açısı aslında Batılılaşma ideolojisinden kaynaklanmaktadır. Batılılaşma ideolojisi ise, Batı'nın ürettiği değerlere aykırı her türlü düşüncenin ortadan kaldırılması gerektiği düşüncesini kendine şiar edinmiştir. Cumhuriyetin kurucu iradesi yaşanılan Bat1lılaşma sorununun müsebbibi olarak Osmanlı ve o dönemin sahip olduğu geleneği göstermiştir. ${ }^{49}$ Her ne kadar Batılllaşma Cumhuriyet umdelerinden biri değilse de, bu ilkelerle yakından bağlantılı olup, bazı yazarlar tarafindan buna modernleşme ya da çağdaşlaşma da denilmiştir. ${ }^{50}$ Batılılaşmanın sağlanmasında ve âdâb-1 muâşeretin öğretilmesinde en önemli organ olarak okul ve basın görülmüştür. ${ }^{51} \mathrm{Bu}$ anlamda son dönem Osmanlı'da Batılılaşma anlayışına misyoner okullarının etki ettiğini iddia edebiliriz. Çünkü 1910 yılında Amerikan misyonerlerine ait 430 okulda 23.474 öğrenci öğrenim görmekte olup, bu sayı o

${ }^{44}$ Cumhuriyet Gazetesi, "Diyanet İşleri Reisi İle Bir Röportaj: Kur'ân-1 Kerim ve Hutbeler Türkçe'ye Tercüme Edilecek” (10.05.1924), 1; Vakit Gazetesi, "Diyanet İşleri Reisi ile Bir Röportaj: Kurân-1 Kerim’in Türkçesi”" (12.05.1926), 1.

45 17.01.1932 tarihinde vefat eden Derviş Paşa için Mustafa Kemal Paşa'nın kaleme aldığı mersiye bu alandaki ilk olma özelliğini taşımaktadır. Hafız Yaşar (Okur) besteleyip defin sonrasında bu ilk mersiyeyi okumuştur. Dücane Cündioğlu, Türkçe Kur'an ve Cumhuriyet İdeolojisi (İstanbul: Kitabevi Yayınları, 1998), 81, 95. Bu mersiye ile birlikte aynı zamanda mezarı başında Şükrü Naili Paşa, Cevdet Kerim bey ve Ali Fethi bey de Derviş Paşa'nın hayatı hakkında konuşma yapmış olup bu husus gazetelerde haber konusu olmuştur. Akşam Gazetesi, "Merhum Derviş Paşa: Cenaze Merasimi Dün İhtifalâtla Yapıldı" (19.01.1932), 2; Akşam Gazetesi, “Türkçe Kur’ân” (21.01.1932), 1-2.

46 İlk Türkçe ezan Hafız Rıfat Bey tarafından Fatih Camii'nde okunmuştur. Akşam Gazetesi, "Türkçe Ezan” (31.01.1932), 2; Cumhuriyet Gazetesi, “ilk Türkçe Ezan Dün Fatih'te Okundu” (31.01.1932), 1.

47 'Tekbir' ve 'Salavat' ile ilgili yasal bir yükümlülüğün olmadığı hususu uzun yıllar anlaşılamamış, Diyanet İşleri Başkanı Ahmet Hamdi Akseki herhangi bir yasaklamanın olmadığını bildiren talimatı konuya açıllı getirmiştir. Bunun için bk. BCA, Fon No: 051.V33.000.000, Kutu No:4, Dosya No:31, Sira No:3.

48 Abdullah Cevdet, “Peyami Safa'ya Mektup”, Türk Düşüncesi 1/1 (1953), 30-31.

49 Hasan Şen, Kemalist Modernleşme ve İslamcı Gelenek (Ankara: Kadim Yayınları, 2012), 59.

50 Seçil Deren, "Kültürel Battlılaşma”, Modern Türkiye'de SiyasîDüşünce: Modernleşme ve Batıcllk (İstanbul: İletişim Yayınları, 2002), 3/382.

51 Nevin Meriç, Âdâb-ı Muâşeret: Osmanl'da Gündelik Hayatın Değişimi (1894-1927) (İstanbul: Kapı Yayınları, 2007), 522. 
dönemki talebe sayısının hemen hemen yarısına tekabül etmektedir. ${ }^{52}$ Tek parti döneminde de okulların modernleşme ve âdâb-ı muâşeret hususunda görev icra ettiklerini dönemin yayınlarından da görmek mümkündür. Örneğin Ragıp Nurettin Eğe tarafından kaleme alınan Muaşeret Kulübü adlı yayın, Kadıköy Erkek Orta Okulu 'muâşeret kulübü' adlı çalışma grubu tarafından bu tür bir hizmet için hazırlanmıştır. ${ }^{53}$

Tek parti döneminde neşredilmiş âdâb-1 muâşeret kitaplarına bakıldığında genel özellikleri hakkında şunları söylememiz mümkündür: Kimi yayınların dili oldukça sadeyken, bazı yayınlarda ağdalı kelimeler kullanılmıştır. Mesela bir kitapta geçen; istiskal, müreccah, tenvir, mütefessih, taayyün, müstekreh, mülevves vb. kelimeler buna örnektir. ${ }^{54}$ Bazı kitaplarda konu anlatılırken maddeleștirilmelere gidilmiş, ${ }^{55}$ bir kaç yayında görsellere de yer verilmiştir. ${ }^{56}$ Ögüt dili ve gereklilik vurgusu yayınların yazım dilinde tercih edilen üslup olarak ön plana çıkmaktadır. ${ }^{57}$ Müslüman kelimesi bazı yayınların önceki baskılarında kullanılmasına rağmen sonraki neşirlerinde yer almamıştır. Bu durumu yayın dilinin sekülerleşmesi olarak değerlendirmek mümkündür. ${ }^{58} \mathrm{Cumhu-}$ riyet döneminde basılmış bazı eserler daha önce neşredilmiş yayınların gözden geçirilmiş halidir. Bu tür yayınlara Lütfi Simavî’nin eserini örnek verilebilir. ${ }^{59}$ Bazı yayınlar hakkında dönemin gazete ve mecmualarında pek çok makale kaleme alınmıştır. Bu duruma örnek olarak Sertelli'nin Çocuklarımıza Muaşeret Dersleri adlı yayını zikretmek mümkündür. Ayrıca Sertelli ve Muzaffer'in eserinde ${ }^{60}$ yer alan bazı yorumları önemsenerek II. Millî Eğitim Şurası'nın gündem maddelerinden biri olmuştur. ${ }^{61} 1925-1945$ yılları arasında neşredilmiş yayınlar hakkında ayrıca şu husus da ifade edilebilir. 1930 öncesi yayınlar, Osmanlı son devri muaşeret kitapları ile büyük ölçüde benzerliklere sahipken, bu tarihten sonra neşredilmiş farklılıkların arz ettiği şeklinde iki kısma ayırmak mümkündür.

\section{Tek Parti Dönemi Âdâb-1 Muâşeret Kitaplarının İçerik İncelemesi}

Araştırmanın kavramsal ve metodolojik çerçevesinde de zikredildiği gibi bu araştırma kapsamında 26 eser ele alınmıştır. Kitaplar değer algısı ve eğitimi açısından tek parti dönemi âdâb-1 muâşeret kitaplarını ferdî, ailevî, toplumsal ve kurumsal olmak üzere konuların ayrıştığı tarafımızca tespit edilmiştir. Birkaç başlık içerisine alınabilecek konular en uygun kısım düşünülerek değerlendirilmiştir. Bu dört başlıkta ele alınan alt başlıklar ve içerikleri hakkında bilgi vermek gerekirse, şunları söylememiz mümkündür.

\footnotetext{
52 Mehmet Altun, “Öğrencilerinin Din Değiștirmesi Üzerine Kapatılan Bir Okul: Bursa Amerikan Kız Koleji”, Toplumsal Tarih Dergisi (Mayis 2003), 27.

53 Ragıp Nurettin Eğe, Muaşeret Kulübü (İstanbul, Kenan Matbaası, 1944), 1-16.

54 İskender F. Sertelli, Çocuklarımıza Muaşeret Dersleri (İstanbul: Tefeyyüz Kitabevi, 1941-1942), 12-79.

55 S. Muzaffer Dalkılıç, Talebeye Muașeret Dersleri, 9.

56 S. Arel, Yemekte Muaşeret (Ankara: İdeal Matbaa, 1939), 15-20.

57 Ural, Tek Parti Döneminde Basılmış Adab-ı Muaşeret Kitapları, 250.

58 Simavi, Teșrifat ve Âdâb-ı Muâşeret, 65.

59 Lütfü Simavi, Teşrifat ve Adab-ı Muâşeret (İstanbul: Kanaat Kütübhanesi, 1340).

60 İskender F. Sertelli'nin Çocuklarımıza Muaşeret Dersleri Adlı Eseri Münasebetiyle Matbuatımızda İntişar Eden Tenkidler (İstanbul: Tefeyyüz Kitabevi, 1941), 9; Süheyla Muzaffer, Modern Adab-1 Muaşeret, 22.

61 Ayhan Öz, "Heyet-i İlmiye Toplantıları ve Millî Eğitim Şûralarında Din Eğitimi”, Sakarya Üniversitesi İlahiyat Fakültesi Dergisi 16/29 (2014/1), 133.
} 


\subsection{Ferdî (Bireysel) Konular}

Âdâb-1 muâşeret kitaplarında ferdî konular genel olarak; temizlik, konuşma, giyimkuşam, ${ }^{62}$ kaşık-bıçak kullanımı ${ }^{63} \mathrm{vb}$. başlıklardan oluşmaktadır. Bu konuların anlatımında diğerlerinde olduğu gibi seküler bir anlayış ve anlatış hâkimdir. Bu durum değer algııının değiștiğinin veyahut değiștirilmek istendiğinin önemli bir göstergesidir. Mesela temizlik başlı̆̆ı dinin emri olarak değil, insan olmanın bir gerekçesi olarak dile getirilmiştir. Bu durumu Dalkılıç'ın; “Artık 'temizlik imandan gelir' sözü temizliğin imana bağlanması demek olan bu dinîh hüviyetinden kurtulmuş 'temizlik hayatın icabıdır' gibi hakikîve içtimai varlı̆ııı bulmuştur" r64 ifadesinde görmek mümkündür.

Yayınlarda ferdî muaşeretin insanoğlu için bir mecburiyet anlamı taşılığına vurgu yapılarak, vazifelerini yerine getiremeyenlerin toplum tarafindan dışlanacağına dikkat çekilmiștii. ${ }^{65}$ Bu sebeple muâşeret bilgisinin aslında insanın kendisi için gösterdiği çaba ile başladığına vurgu yapılmıştır. ${ }^{66}$ Kişisel bakıma ve muâşerete uymanın bir diğer faydası ise, devletin bekasına yöneliktir. Çünkü kendisine iyi bakan bir kişi, zamanı geldiğinde devletine karşı sorumluluklarını yerine getirebilir, anlayışı hâkimdir. Bu duruma; "Türk genci, temiz olmadı̆̆ zaman muzdarip olmaldır ki, Cumhuriyet in kendisinden beklediği önce șahsını ve sihhatini koruma vazifesini yapabilsin ${ }^{367}$ ifadesini örnek vermek mümkündür. Bazı yayınlarda bu tür durumlar, dinî içerikli ifadelerle anlatılmıştır. Mesela, çalışkanlığın önemi anlatılırken tembelliğin Allah katında sevilmeyen bir davranış olduğuna dikkat çekilerek değinilmiştir. ${ }^{68}$ Bu durum $1940^{\prime} l ı$ yılların başında daha da aşikâr görülen ahlak buhranından kaynaklanmış olabileceği gibi yazarın kişisel bakış açısından ileri gelmesi mümkündür.

Muâşeret kitaplarında erkek ve kadınlara yönelik uyarılarda bulunulmaktadır. Bu uyarılar tek parti dönemi uygulamalarını destekler mahiyettedir. Aşağıdaki ifadelerde bu durumu görmek mümkündür:

Türk Cumhuriyeti, giyim üzerinde inkılap yapmıştır. Şalvar ve çarşafı kaldırmış, fes menolunmuştur. Güneşten, havadan tıpkı bir erkek gibi istifade etme hakkı olan kadını bir kese kâğıdına sarılmış herhangi bir yemiş gibi siyah çarşaf içine sarıp sarmalamak kadar manasız bir şey düşünülebilir mi? uzviyetin rahatını ihlal eden ayak bileklerinden sıkıştırılmıș bir şalvarın acayipliği inkâr olunabilir mi? Nihayet tabiatın icaplarına göre bulunmuş ve tekâmül ettirilmiş şapka dururken arkasında kocaman ve manasız bir püskül sallanan kıpkırmızı bir fes giyilebilir mi? Kıyafet inkılabımız, yurdumuza saç temizliği, vücut temizliği, kadın ve erkek müsavatını, bütün medenî dünyanın birlik gösterdikleri muaşeret ve adabı sokmuş bulunuyor." ${ }^{69}$ Benzer görüşü savunan bir başka yazar ise fikirlerini şu şekilde dile getirmiştir: Büyük inkılabımız kadını kafesten, peçeden kurtardıktan ve taassubu kırıp attıktan sonra, Garbın medenî kaidelerini millî șiarımız haline sokmuştur. Türk kadını medenî bir insan sıfatı ile cemiyet hayatına karışınca adabı muaşerete vakıf olmak işi büsbütün ehemmiyet kesp etmiștir. ${ }^{70}$

62 Sezai Tuncalı, Âdâb-ı Muâşeret (H.O. Basımevi, 1940), 8.

63 Arel, Yemekte Muâşeret: MuhtelifMasaların Tertibi, 7.

64 Dalkılıç, Talebeye Muașeret Dersleri, 3.

65 Dalkılıç, Talebeye Muaşeret Dersleri, 9.

66 Muzaffer, Modern Adab- 1 Muaşeret, 14.

67 S. Muzaffer Dalkılıç, Talebeye Muașeret Dersleri, 11.

68 Bahri Özdeniz, Sosyal Tam Âdâb-ı Muâşeret (İstanbul: İkbal Kitabevi, 1942), 31.

69 S. Muzaffer Dalkılıç, Talebeye Muaşeret Dersleri, 23.

70 Savaşçin, Âdâb-ı Muâşeret, 2. 
Tek parti döneminde önemli görülen giyim-kuşamla ilgili fes, sarık, çarşaf vb. yasaklamalar CHP kurultaylarında müzakere edilmiştir. Dördüncü Büyük Kurultay bu duruma örnektir. ${ }^{71}$ Bu hususlar ayrıca mezkûr dönemi araştıranlar için de bir konu olarak hâlâ zihinleri meşgul etmektedir. ${ }^{72}$

Bu durumu bazı araştırmacılar, Cumhuriyet ideolojisi ve reformlarını kabul etme ile dönemin giyim anlayışı arasında anlamlı bir ilişki olduğu şeklinde yorumlamış ve buradan hareketle Cumhuriyet dönemi giyim-kuşam anlayışında eskiye nispeten tek tipleștiren bir bakış açısının hâkim olduğunu iddia etmiştir. ${ }^{73}$ Âdâb-ı muâşeret kitaplarında giyim-kuşam konusu öğrenim seviyesine göre dile getirilmeye çalışlarak okulların bu hususta verdiği kararların uygulanması gerektiğine vurgu yapılmış, ayrıca giyim-kuşamda önemli olanın sadelik ve temizlik olduğuna, yerli ürünlerin kullanılması gerektiğine dikkat çekilmiştir. ${ }^{74}$

Yayınlarda özellikle genç kızların dikkat etmesi gereken hususlara önem verilerek, "açık-saçık elbiselerin giyilmemesi" ${ }^{\text {"75 }}$ ve odalarının duvarlarına artist resimleri asmalarının uygun olmayacağı, bu tür bir davranışın ruhî zaafa delalet etme şeklinde yorumlanacağı belirtilmiştir. ${ }^{76}$ Erkeklerle ilgili olarak ise, kitaplarda değinilen en önemli konulardan birisini kişisel bakım hususu oluşturmaktadır. Kişisinin kendisine karşı kayıtsız ve derbeder olmasının toplum tarafindan kabul edilmeyeceği hatta istikbalini olumsuz etkileyeceğine vurguyapılmıştır. ${ }^{77}$ Bazı yayınlarda temizliğin dinî yükümlülük olduğu da belirtilmiştir. ${ }^{78}$

Erkeklerin kişisel bakımıyla ilgili en önemli husus tıraş olma alışkanlığıdır. Yayınlarda tıraş olmanın önemi vurgulanırken, saç boyatmanın ise uygun olmadığı ifade edilmiştir. ${ }^{79}$ Sakal ve bıyık tıraşında meydana gelen algısal dönüşüm hakkında ise şu malumatlar dönemi anlama adına önem arz etmektedir:

Evvelden erkek denince sakal ve bıyık hatıra gelirdi. Bugün böyle bir şey olmamakla beraber yine eski ananeye uyarak sakal ve bıyıktan başlayalım. Filhakika sakal, taş devri insanlarından tâ genel harbe gelinceye kadar erkek kudret ve azametinin bir timsali idi. Tarihin siması hemen hemen sakallıdır denebilir. İnsanlar Allahlarını bile sakallı tasavvur etmişlerdir... Velhasıl bütün beşeriyet için sakal, genel harbe kadar asırlarca kudret ve kuvvetin alameti sayılmıştır. Gariptir ki; genel harp sanki beşeriyetin sakalı üzerinden geçmiştir. Cihan harbi insanların sakalını bıyığını alıp götürdü. Bugünün muaşeretinde sakal o derece haramdır ki, tıraş olmaksızın hiçbir ziyaret yapılamaz. ${ }^{80}$

Tuncalı'nın "haram" ifadesinin bir benzerini Simavi'de de görmek mümkündür. Simavi muâşeret kurallarına uymanın "farz" olduğunu belirtmiş, topluluk içerisinde din ve mezhep konularının konuşulmasını ise, "câiz" görmemiştir. ${ }^{81}$

71 CHP Dördüncü Büyük Kurultayı Görüşmeleri Tutulgast (9-16 Mayıs 1935) (Ankara: y.y., 1935), 144-159.

72 Bunlardan bazıları için Bk. Hakkı Uyar, “Çarşaf, Peçe ve Kafes Üzerine Bazı Notlar”, Toplumsal Tarih Dergisi (Eylül 1996), 6-11; Deren, Kültürel Batılllaşma, 382-402.

73 Deren, Kültürel Batılllaşma, 388.

74 Dalkılıç, Talebeye Muaşeret Dersleri, 13-21.

75 Muzaffer, Modern Adab-ı Muaşeret, 36.

76 Samih Nafiz Tansu, Talebeye Muâşeret Usulleri (İstanbul: Kanaat Kitabevi, 1939), 35.

77 Tuncalı, Âdâb-ı Muâşeret, 8.

78 Simavi, Teşrifat ve Âdâb-ı Muâşeret, 61.

79 Muzaffer, Modern Adab-ı Muaşeret, 25.

80 Tuncalı, Âdâb-1 Muâşeret, 10-11. Sezai Tuncalı bu görüşü Dalkılıçtan aldığı görülmektedir. Bk. Muhittin Dalkılıç, Yeni Hayat Adamına Yeni Adab-ı Muaşeret (İstanbul: Suhület Kütüphanesi, 1932), 96-97.

81 Lütfi Simavi, Teşrifat ve Âdâb-ı Muâşeret (İstanbul: Marifet Matbaası, 1926), 36-38. 
Ferdî konulardan bir diğeri konuşma muâşeretidir. Hz. Peygamber'e ait olan; "Daima muhatap olduğunuz seviyeye göre konuşunuz" ifadesi hadis-i şerif olduğu belirtilmeden kullanılmıştır. ${ }^{82}$ Konuşma adâbının sergilenmesi gereken en önemli ortamların münakaşa zamanlarında olduğuna dikkat çekilerek, öğretmenlerin bu konuda öğrencilerini yetiştirmesi gerektiğine vurgu yapılmıştır. ${ }^{83}$

\subsection{Ailevî Konular}

Eğitim-öğretimle ilgili yayınlarda olduğugibi âdâb-1 muâşeret kitaplarında da görgü ve nezaketin temelinin ailede başlayacağı vurgulanmıştır. ${ }^{84}$ Çünkü aile; muâşeret bilgisinin ilk öğrenildiği mekân olup, burada edinilen bilgiler toplum içerisinde sergilenmektedir. Yayınlarda aile üyelerinin giyim-kuşam özelliklerinin modern toplumlarda birbirine benzediğine dair örnekler verilmiştir. Bu eserlerin bazısında İngiliz, ${ }^{85}$ kiminde Fransız, ${ }^{86}$ bir takım yayınlarda ise Alman ve İtalyan âdâb-1 muâşeretinin örnek alındığı görülmektedir. ${ }^{87}$ Bununla birlikte, yayınlarda ailede âdab-ı muâşerete dair başlıklara önem verilip geniş bir şekilde ele alındığını söylemek mümkündür. ${ }^{88}$ Bu konunun önemsenmesinin sebeplerinden birini devletin makbul vatandaş yetiştirme anlayışından ileri gelmektedir. Bu durum; "yattığı ve büyüdüğü, okuyupyaşadığıyere hürmeteden, bakan bir adam, yarın kendisine emanetedilen yurdunu da böylece tam bir titizlikle slyanet eder" denilerek açlkça ifade edilmiştir. ${ }^{89}$

Aile muâşeretinde ele alınan ilk konuyu evlenme hususu oluşturmaktadır. Evlenirken dikkat edilmesi gereken durumlar; "Zevc ve zevcenin küfüv (denk) olmast şartttr. Dinen de böyledir. Muhtelif terbiye ve nazariye dairesinde büyümüş, ayrı tabakalara mensup eşhas imtizaç edemezler. Avrupal kadınlarla izdivaç da ekseriya iyi netice vermez. Din, iklimi muhit ve hissiyatın ilk tesirleri zâil olmaz"${ }^{190}$ denilerek erkeklerin kendi muhitlerindeki dengi kişilerle evlenmesinin uygun olacağı ifade edilmiştir. Düğün planlaması yaparken davet muaşeretine özen gösterilmesi gerektiği, telefon ile haber vermenin uygun olmayacağı dile getirilmiştir. ${ }^{91}$ Evlilikle ilgili değișen bir muâşeret ise gelin-damadın düğün sonrasında balayına gitmesi olduğu görülmektedir. ${ }^{92}$ Bir diğer değişen yaklaşım ise kadın ve erkeğin eşit haklara sahip olduğunun vurgulanmasıdır. ${ }^{93}$

Anne-babanın öğreteceği âdâb-ı muâşeret için çocuğun alıcılarının açık olması gerektiğine değinilerek, büyüklerin tembihlerinin dışına çıkılmaması gerektiği dile getirilmiştir. ${ }^{94}$ Bazı yayınlarda tek parti döneminde âdâb-ı muâşeretin en mütekâmil hali bulduğuna, ${ }^{95}$ eski

82 S. Muzaffer Dalkıliç, Talebeye Muaşeret Dersleri, 27.

83 S. Muzaffer Dalkılıç, Talebeye Muaşeret Dersleri, 33.

84 Nilgün Sevinç, Protokol Bilgisi (Ankara: Detay Yayınları, 2004), 1.

85 Sertelli, Talebeye Muaşeret Dersleri, 11, 15-16.

86 Feliha Sedat, Genç Kızlara Muaşeret Usulleri (İstanbul: Muallim Ahmet Halit Kitaphanesi, 1932), 5.

87 Muhittin Dalkılıç, Yeni Hayat Adamına Yeni Adab-ı Muaşeret (İstanbul: Suhület Kütüphanesi, 1932), 9.

88 İskender F. Sertelli, Çocuklarımıza Muaşeret Dersleri (İstanbul: Tefeyyüz Kitabevi, 1941-1942), 1-33.

89 Dalkılıç, Talebeye Muaşeret Dersleri, 35.

90 Simavi, Teşrifat ve Âdâb-1 Muâșeret, 18.

91 S. Arel, Halkve Talebeye Muaşeret Bilgileri (Ankara: İdeal Matbaa, 1939), 20.

92 Özdeniz, Sosyal Tam Âdâb-ı Muâșeret, 123.

93 Özdeniz, Sosyal Tam Âdâb-ı Muâşeret, 19.

94 Tansu, Talebeye Muâşeret Usulleri, 23.

95 Sertelli, Çocuklarımıza Muaşeret Dersleri, 33 
aile tipinde çocuğa söz hakkı verilmezken yenisinde bunun olduğuna değinilip övünülürken, ${ }^{96}$ diğerlerinde ise "bazı eski aileler istisna edilirse bu iyi terbiye de ma'atteessüf yavaş yavaş zail olmaktadır" ifadeleriyle âdâb-1 muâşereti açısından Osmanlı ailesindeki uygulamalarının aranılır hale geldiğine vurgu yapılmıştır. ${ }^{97}$ Bununla birlikte, tek parti dönemi âdâb-1 muâşeret anlayışında sadece aile üyeleri arasındaki ilişki değişmemiş, aynı zamanda evdeki odaların düzenlenmesi, ${ }^{98}$ evlere ayakkabı ile girilmesi ${ }^{99}$ ve yılbaşı kutlamaları gibi yeni eğlence türleri hakkında uygulamalar dile getirilmiştir. ${ }^{100}$ Ayrıca yakınını kaybeden bir kişinin matem süresi de dile getirilmiştir. ${ }^{101}$

Bazı yazarlar ebeveynin çocuklarına bırakacağı en güzel hazinenin ahlak ve terbiye olduğuna dikkat çekip, bunun eğitim-öğretim ile muvazi gitmesi ve desteklenmesi gerektiğini ifade ederken, ${ }^{102}$ kimi ise; bu görüşü benimsememektedir. ${ }^{103}$ Annebabanın misafirlerine karşı âdâb-ı muâşeret kurallarını uygulayarak yeni nesle öğretmesi gerektiğine dikkat çekilmiştir. ${ }^{104}$ Muâşeretin kazandırılmasında annenin acıma, sevgi ve şefkat gibi hislere sahip olması sebebiyle en iyi mürebbiye olduğu vurgulanmıştır. ${ }^{105}$ Kendisine sevgi ve acıma hissiyle yaklaşan ebeveynine karşı hürmet göstermesi ve ellerini öpmesi gerektiği belirtilmiştir. ${ }^{106}$ Yayınlarda el öpme âdetinin toplum tarafından olduğu gibi yazarlarca geleneksel anlayışla devam etmesinin vurgulandığ 1 görülmektedir.

Erkeğin hanımı hakkında bahsederken; "bizim hanım" ifadesini değil, "refikam" tabirini kullanması gerektiğine değinilmiş ${ }^{107}$ bazı yayınlarda ise "zevce" veya "refika" kelimelerinin uygun olmayacağı belirtilerek "karı" ifadesinin tercih edilmesi hususuna dikkat çekilmiştir. ${ }^{108}$

Âdâb-1 muâşeret kitaplarında çok eşlilik konusuna değinilmemektedir. Bunun sebebi olarak Alan Duben ve Cem Bahar'ın ampirik veriler kullanarak yaptıkları çalışmada da görüleceği üzere Türk-İslam kültüründe çok eşliliğin yaygın olmamasından kaynaklanmış olabilir. ${ }^{109}$

96 Sertelli, Çocuklarımıza Muaşeret Dersleri, 31-32.

97 Simavi, Teşrifat ve Âdâb-ı Muâşeret, 39; Benze bir durum için lütfen bakınız: Özdeniz, Sosyal Tam Âdâb-ı Muâşeret, 106-109.

98 Sertelli, Çocuklarımıza Muaşeret Dersleri, 42.

99 Tuncal, Âdâb-1 Muâşeret, 5.

100 Arel, Yemekte Muaşeret, 17. Yılbaşı kutlamaları Refik Halit Karay’a göre İstanbul'un işgal yılları ile birlikte başlamıştır: Refik Halit Karay, “Eski ve Yeni Yılbaşı Geceleri”, Panoroma (Ocak 1955), 4-5.

101 Özdeniz, Sosyal Tam Âdâb-ı Muâşeret, 128-129.

102 Özdeniz, Sosyal Tam Âdâb-ı Muâșeret, 17.

103 Simavi, Teşrifat ve Âdâb-ı Muâşeret,17.

104 Simavi, Teşrifat ve Âdâb-ı Muâşeret, 51, 61.

105 Okçabol, Meslek Terbiyesi: Muâşeret Teşkilat, Fiili Hizmet ve Zabıta Tarihi Ders Kitabı, 21.

106 Sertelli, Çocuklarımıza Muaşeret Dersleri, 18-19.

107 A. Lutfullah, Zabitan İçin Muaşeret Usulleri ve Beynelmilel Teşrifat Kaideleri (İstanbul: Kader Matbaası, 1932), 100.

108 Muzaffer, Herkes İçin Modern Âdâb-1 Muâşeret, 163.

109 Alan Duben - Cem Bahar, İstanbul Haneleri: Evlilik, Aile, Doğurganllk 1880-1940 (İstanbul: İletişim Yayınları, 1996), 61-100, 171-172. 


\subsection{Toplumsal Konular}

Toplumsal bir varlık olan insanoğlunun hür olmadığına, ${ }^{110}$ sokakların resmî mekânlar olduğuna ${ }^{111}$ dikkat çekilen âdâb-ı muâşeret kitaplarında uyulması gereken bazı toplumsal kurallar konu edilmiştir. ${ }^{112}$ Toplumsal kurallara uyulmadığı takdir de efkâr-1 umûmiyenin kişiyi cezalandıracağı belirtilmiştir. ${ }^{113}$

Cumhuriyet sonrası Türkiye'sinde, toplumsal âdâb-1 muâşeret konularında pek çok değişiklik meydana gelmiştir. İlgili yayınlarda ele alınan toplumsal konulara dair bazı alt başlıklar şunlardır: Giyim-kuşam, el öpme, konuşma, tanışma, selamlaşma, ziyaret, yemek yeme, dans, genç kızlar ve toplumsal ahlâkî hususlar, ${ }^{114}$ cemiyet içerisinde yapılmaması gereken davranışlar, ${ }^{115}$ sinema-tiyatro ve konser alanı gibi umumî alanlarda gösterilecek usuller, ${ }^{116}$ sigara ve içki içme adabi, ${ }^{117}$ balo ve dans muâşereti ${ }^{118}$ ev sahibi ve misafirin uyması gerekenler ${ }^{119}$ ve okul kuralları. ${ }^{120}$

Âdâb-1 muâşeret kitaplarında toplumsal konular dile getirilmedenönce başlıkla ilgili bazı kavramlar açıklanmıştır. Mesela bunlardan bir tanesi hürriyettir. İnsanoğlunun hürriyetinin sınırlı olduğuna dikkat çekilen yazılarda kişinin devletine ve milletine karşı sorumlu olduğu ifade edilmiştir. Yazarların bir kısmına göre toplumsal konularda muâşerete bağlı kalmak vicdandan değil, bulunduğu ortama ayak uydurma gerekliliğinden kaynaklanmaktadır. ${ }^{121}$ Savaş sonrasında kadın ve erkeklerin hayatlarının mühim bir kısmını lokanta, sinema, tiyatro vb. muhtelif ev dışı mekânlarda geçirmesi, muâşerete dair hususları önemsemesini gerektirmiştir. ${ }^{122}$

Toplumsal hayatta giyim-kuşam en önemli muâşeret başlıklarından biri olarak görülmüştür. Çünkü giyim-kuşam insanoğlunun toplum içerisindeki yerinin belirlenmesinde önemli rol oynamaktadır. ${ }^{123}$ Bu sebeple; "kıravat; erkek giyiminin barometresidir"124 denilerek konunun önemine dikkat çekilmiştir. ${ }^{125} \mathrm{Bu}$ durum giyim-kuşamda halkın tercih ettiği bazı kıyafetler yok sayılmaya, reddedilmeye hatta aşağılanmaya çalışılarak; "Peçeyi gömeli çok oldu zaten. Türk’ün malı olmayan peçe tarihe karışmıştır. Öyle iken şurada burada peçe yerini iki kat tutacak derecede başları karalarla sarılı kadınlar görüyoruz. Bu umacı manzara Kayseri'nin zeki ve uyanık halkı ile tezad teşkil etmektedir"126 ifadeler ile bazı kıyafetlerin geçmişte

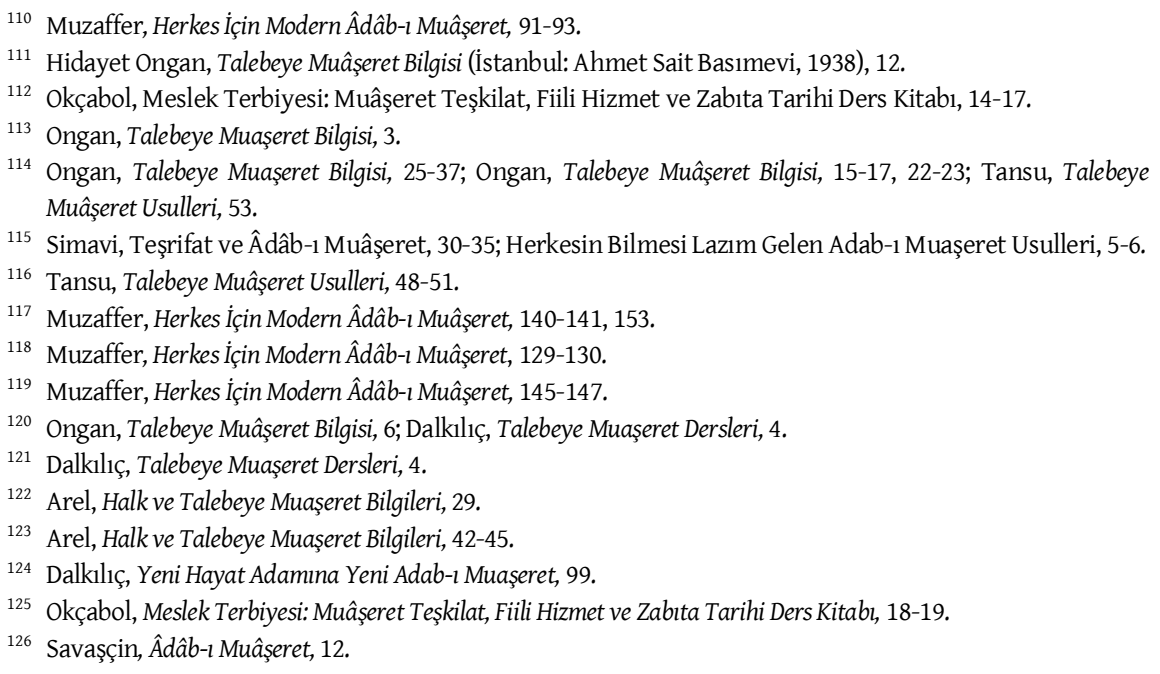


kaldığı ileri sürülmüş, giysi ve şapka inkılabına uyanların münir kişiler olduğu belirtilmiştir. ${ }^{127}$ Bununla birlikte, dekolteli elbiselerin giyilmemesi gerektiğine dikkat çekilerek, bunun toplum içerisinde çirkin dedikodulara sebebiyet vereceğine vurgu yapılmıştır. ${ }^{128}$ Bu durum, her ne kadar Batı medeniyetinin kıyafetini kabul etmiş olsak da, Avrupa âdâb-1 muâşeretinde giyim-kuşamda çıplaklığa doğru giden kaidenin takip edilmemesi gerektiği belirtilerek anlatılmıştır. ${ }^{129}$ Ayrıca günlük hayatta çok kullanılan giyim-kuşamla ilgili materyaller, ${ }^{130}$ az ya da hiç kullanılmayan elbiseler ${ }^{131}$ ve giyim tarzının hangi sınıfa tabi olunduğuna dair bir gösterge oluşuna değinilmiştir. ${ }^{132}$

Diğer muâşeret hususlarında olduğu gibi el sıkma ve öpme ile ilgili anlatımlarda da Batı tarzı uygulamalar söz konusudur. 1930 öncesi yayınlarda kadınların elinin öpülmesine pek rastlanmazken, ${ }^{133}$ sonrası eserlerde bu durum hakkında çokça malumat yer almıştır. Bu hususun tarif edildiği eserlerde el öpülürken alına götürmenin eski bir adet olduğu dile getirilerek, yapılması gereken davranış tarif edilmiştir. ${ }^{134}$ Ayrıca insanların hem cinsleri ile tokalaşırken kucaklaşmasının eski bir adet olduğuna dikkat çekilerek, bundan vaz geçilmesi gerektiği vurgulanmış, ${ }^{135}$ tanışma-tanıtma ile ilgili bazı hususlara da değinilmiştir. ${ }^{136}$ Sağ el ile tokalaşmanın "elimde silah yok benden sana zarar gelmez demenin ifadesidir"137 anlamına geldiğine dikkat çekilerek, karşı cins ile tokalaşmanın ancak kadının el uzatması ile mümkün olacağ 1 ifade edilmiştir. ${ }^{138}$

Toplumsal muâșeret konularından birini selamlaşma adâbı oluşturmaktadır. $\mathrm{Bu}$ âdâbın hangi kelimelerle yapılacağı 1930 öncesi yayınlarda tarif edilmemiştir. ${ }^{139} 1930$ sonrası yayınlarda ise bu âdâbın oldukça seküler şekilde uygulandığını söylemek mümkündür. Bu durumu; "Biz Türkler ne eski devirlerin şark an'anesinde görülen ve biraz da dinî olan săg eli kalbimizin üstüne götürerek softa selamın, ne de Almanların sağ eli dirsek hizasında veya İtalyanlarda olduğu gibi sağ eli yukarı kaldırmak şeklindeki selam tarzlarını kullanamayız"140 şeklindeki ifadelerde görmek mümkündür. Benzer şekilde Sertelli, Arel ve Ongan'ın kitaplarında da selam için "günaydın" gibi seküler kelimelerin kullanılmasının uygun olacağı belirtilmiştir. ${ }^{141}$

\footnotetext{
127 Sahir, Alem-i Medeniyette Adab-ı Muaşeret Elbise ve Şapka Giymek Usulleri, 2.

128 Tansu, Talebeye Muâşeret Usulleri, 16-17, 33.

129 Dalkılıç, Yeni Hayat Adamina Yeni Adab-ı Muaşeret, 84-85.

130 Özdeniz, Sosyal Tam Âdâb-ı Muâşeret, 73.

131 Muzaffer, Herkes İçin Modern Âdâb-ı Muâșeret, 120-124.

132 Herkesin Bilmesi Lazım Gelen Adab-ı Muașeret Usulleri, 4.

133 Cahid Sahir, Alem-i Medeniyette Adab-ı Muaşeret Elbise ve Şapka Giymek Usulleri, 9.

134 Muzaffer, Modern Adab-ı Muaşeret, 70-74; Simavi, Teşrifat ve Âdâb-ı Muâşeret, 11-13.

135 Muzaffer, Modern Adab- 1 Muașeret, 74-76.

${ }^{136}$ Muzaffer, Modern Adab- 1 Muașeret, 77-83.

137 Dalkılıç, Yeni Hayat Adamına Yeni Adab-ı Muașeret, 18.

138 Tuncalı, Âdâb- 1 Muâșeret, 29, 32

139 Cahid Sahir, Alem-i Medeniyette Adab-ı Muașeret Elbise ve Şapka Giymek Usulleri, 7-9.

140 Tansu, Talebeye Muâșeret Usulleri, 10.

141 Sertelli, Çocuklarımıza Muaşeret Dersleri, 96; Arel, Halk ve Talebeye Muaşeret Bilgileri, 5; Ongan, Talebeye Muâşeret Bilgisi, 6-7.
} 
Selamlamanın bazı kişi, grup veya kurumlara karşı zorunlu olarak yapılması gerektiği ifade edilmiştir. Bunları; cenazenin, ${ }^{142}$ Türk bayrağı-sancağının ${ }^{143}$ ve başka devlet bayraklarının selamlanması olarak ifade edebiliriz. Selamlamanın nasıl yapılması gerektiği hususu hakkında bilgiler verilmektedir. ${ }^{144}$ Selamlanması zorunlu olan bir diğer grup ise, asker ve polislerdir. Bu hususta "Her Türk bilir ki, dünyada en şerefli asker Türk askeridir. Türk askerinin toplu bulunduğu her yerde, her vatandaş bu asil ve şerefli orduyu selamlamaya mecburdur... Onu atası, İnönü'sü bile takdir ettikten sonra Türk vatandaşına, saygıdan başka bir şey kalmaz"145 denilerek mecburen yapılması gerektiğine dikkat çekilmiştir. Sokakta selamlaşma esnasında şapkanın nasıl çıkarılacağ $1{ }^{146}{ }^{14}$ çocuk-yetişkin, kadın-erkek arasındaki usulü ${ }^{147}$ ve uzun süre yurt dışında kalanların uyması gereken kurallar $^{148}$ hakkında malumatlar verilmiştir.

Toplum içerisinde konuşma kişinin edindiği âdâb-1 muâşereti gösteren en önemli gösterge olarak kabul edilmiş ve ele alınan bir konu olmuştur. ${ }^{149}$ Bu sebeple ileri boyutta tartışmalara sebebiyet verecek konulara girilmemesi gerektiği, özellikle dinî hususlarda münakaşa yapılmamasına dikkat çekilmiştir. ${ }^{150}$ Toplum içerisinde doğru konuşmanın kazandırılabilmesi için kelimelerin nasıl telaffuz edilmesi ve kullanılması gerektiğine yönelik bazı kelimelere yer verilmiştir. ${ }^{151}$ Bazı yayınlarda ise yüksek mevkideki kişilere karşı "Üstad"152 ile dinî bir ifade olan "Estağfirullah"153 kelimesinin ve evcil hayvanlarımıza herhangi bir milletin isminin takılmasının uygun olmadı̆̆ı ifade edilmiştir. ${ }^{154}$ Konuşma muâşereti ile ilgili bir diğer husus, tanışma sürecinde kullanılacak ifadelerdir. ${ }^{155}$ Bunların yanlış kullanılmasının sebebi ise, genç neslin yeterince okumamasından kaynaklı fikir ve mefhum kıtlı̆̆ından ileri gelmektedir. ${ }^{156}$

Âdâb-ı muâşeret kitaplarında ele alınan en önemli başlıklardan bir diğeri kadınlarla ilgili konulardır. Eserlerde kadınların muâşeret kurallarına muhakkak dikkat etmesi gerektiğine dikkat çekilmiş, bunun mecburiyet teşkil ettiği ifade edilmiştir. ${ }^{157}$ Muâşeretten kastın yapmacıklı davranışlar olmadığı özellikle vurgulanmıştır. ${ }^{158}$ Feliha Sedat genç kızların ve kadınların toplum içerisinde uyması gereken âdâb-ı muâşerete yönelik pek çok başlığa yer vermiştir. Eserinde bir taraftan genç kızların geçmişe oranla daha fazla imkâna

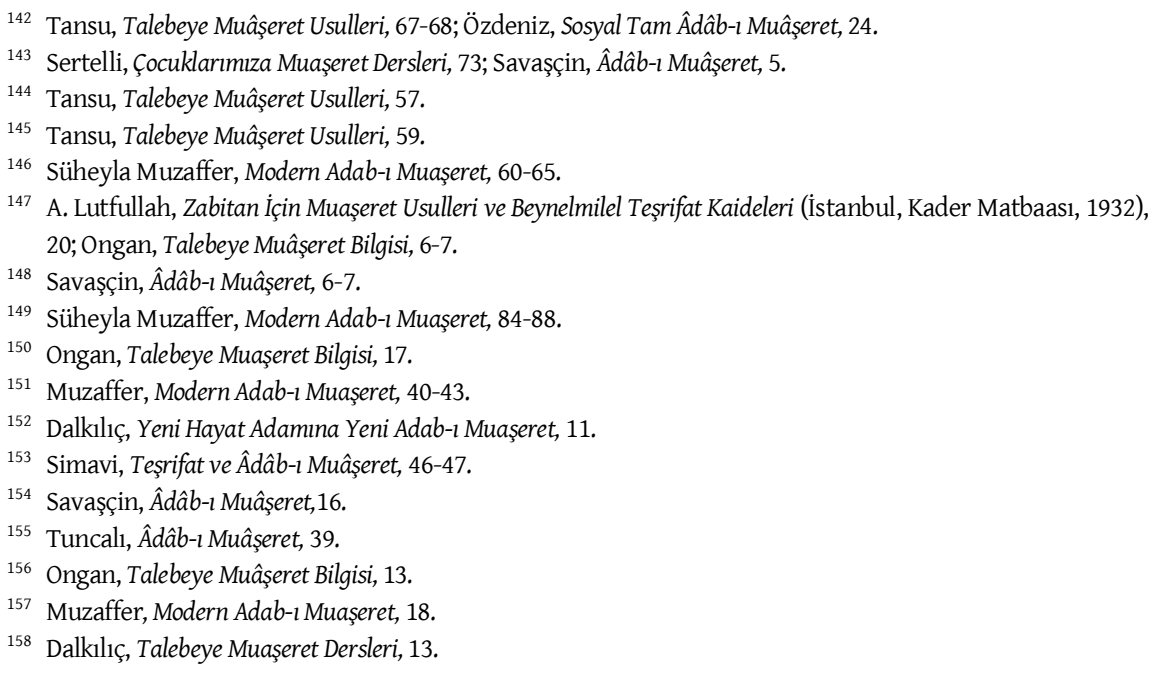


sahip olduklarını belirtirken, diğer taraftan bu özgürlüğün sınırları hakkında malumatlar vermiştir. Mesela kızların toplum içerisinde erkekler gibi giyinmesinin, ${ }^{159}$ pahalı mücevherat kullanmasının uygun olmadığı ifade edilmiștir. ${ }^{160}$ Ayrıca bir kadın, pastaneye girmek durumunda kalırsa masaya yerleşmemek şartıyla pastayı ayakta yiyip çıkması, ${ }^{161}$ tek başına konsere ${ }^{162}$ veya sinemaya gitmemesi önerilmiştir. Çünkü tek başına giderse "bu vaziyette görülen bir kızdan herkesin şüphe etmekte hakkı olabilir"163 diyerek kendi içerisinde çelişen bir tavır sergilemiştir. Aslında bu durumdan, sadece Türkiye'de değil Fransa'da da mezkûr dönemde genç kızların tek başına sokağa çıkmadığı anlaşılmaktadır. ${ }^{164}$ Türkiye'deki hanımlar ise, Avrupalı hemcinslerinin sokak vb. sosyal ortamlarda çok vakit geçirdikleri gibi bir zanna kapıldıklarına da dikkat çekilmiştir. ${ }^{165}$ Eserlerde hamile ve hasta bayanların sokağa çkmasının uygun görülmemesi ise oldukça ilginçtir. ${ }^{166}$ Ural bu durumu tek parti anlayışının genç kız ve kadınlara yüklediği modern davranışları sergileme yönündeki görev anlayışından kaynaklandığı șeklinde yorumlamaktadır. ${ }^{167}$

Genç kızlar için mahzurlu olan bir diğer durumun erkeklerle samimi bir şekilde el sıkışma olduğu; "el elde ne kızın kızla, ne erkeğin erkekle konuşması doğru olmadığı gibi hiçbir zaman bir kızın bir erkekle bu tarzda konuşması da caiz değildir" ${ }^{168}$ diyerek dinî gerekçelendirmeye gidilmiştir. Ayrıca erkeklerle arasına mesafe koymas ${ }^{169}$ ve sokakta yürürken her ne sebeple olursa olsun şapkasını başından çıkarmaması gerektiği vurgulanmış, ${ }^{170}$ toplum içerisinde konuşurken elini-kolunu hareket ettirmesinin hoş karşıllanmayacağ ${ }_{1}^{171}$ ifade edilmiştir. Genç kızların bu davranışları öğrenebilmesi için âdâb-ı muâşeret başlıklı kitaplar neşredildiği gibi farklı kelimeleri kullanıp içerisinde görgü kurallarından bahseden eserler de neşredilmiştir. ${ }^{172}$

Genç kızların bilmesi gereken en büyük maharet ve spor olarak dans etme olduğu ifade edilmiştir. Hatta "Bu asirda her kadın ve erkek için hiç olmazsa Fokstrot, Tango, Vals bilmek medenîbir ihtiyaçtır"173 denilerek dans, muasır medeniyetin müşterek malı olarak gösterilmiştir. ${ }^{174}$ Yayınlardaki; "dans ederken sakı çiğnemek caiz değildir"175 gibi bazı ifadeler ise, eserlere kendi içerisinde çelişen bir hal katmıştır.

159 Sedat, Genç Kızlara Muașeret Usulleri, 34-35.

160 Sedat, Genç Kızlara Muaşeret Usulleri, 67.

161 Sedat, Genç Kızlara Muaşeret Usulleri, 36-37.

162 Sedat, Genç Kızlara Muaşeret Usulleri, 113.

163 Sedat, Genç Kızlara Muaşeret Usulleri, 37.

164 Simavi, Teşrifat ve Âdâb-ı Muâşeret, 43.

165 Simavi, Teşrifat ve Âdâb-ı Muâşeret, 42.

166 Okçabol, Meslek Terbiyesi: Muâşeret Teşkilat, Fiili Hizmet ve Zabıta Tarihi Ders Kitabı, 31.

167 Tülin Ural, “1930'larda Âdâb-1 Muaşeret Kitaplarında Kadın İmgesi”, Toplumsal Tarih Dergisi 231 (Mart 2013), 91.

168 Tansu, Talebeye Muâşseret Usulleri, 14-15.

169 Herkesin Bilmesi Lazım Gelen Adab-ı Muaşeret Usulleri, 16.

170 Sedat, Genç Kızlara Muaşeret Usulleri, 33.

171 Sedat, Genç Kızlara Muaşeret Usulleri, 32.

172 S. Arel, Genç Kız ve Kadınlarımızın Cemiyette Seçecekleri Muhtelif Mesleklere Göre Kendilerinde Bulunması Lazım Gelen Vasıflar, 1-34.

173 Savaşçin, Âdâb-ı Muâşeret, 20.

174 Okçabol, Meslek Terbiyesi: Muâşeret Teşkilat, Fiili Hizmet ve Zabıta Tarihi Ders Kitabı, 67.

175 Okçabol, Meslek Terbiyesi: Muâşeret Teşkilat, Fiili Hizmet ve Zabıta Tarihi Ders Kitabı, 69. 
Hizmetçisi olan kadınların onlara karşı hilm ve şefkatle muamele etmesi gerektiğine denilerek ${ }^{176}$ dinî gerekçelendirmelerde bulunulmuştur. Araba ile seyahat esnasında iki erkek bir kadın bulunursa kadın mutlaka ortaya alınır ${ }^{177}$ denilerek farklı bir izlenim çizilmiştir. Her ne kadar bu durum Simavi ve Savaşçin'in farklı anlayışlarından kaynaklansa da, Savaşçin'in “evde kocası yokken kadını ziyaret etmek doğru değildir ${ }^{178}$ ifadesi daha önceki görüşleri ile çelişmektedir.

Genç kızlara bu ögütlerin verilmesinin sebebi ise, hayat şartlarının değişmesi ${ }^{179}$ sebebiyle nasıl davranacaklarını bilmemeleridir. ${ }^{180}$ Artık genç kızlar toplumsal hayat içerisindedir. Avrupa'da bazı ülkelerde olduğu gibi kadın ve erkeklere özel plajların tercih edilmesi gerektiği öğütlenmiştir. ${ }^{181}$ Kendileri için düzenlenmiş balolara gitmeleri uygun görülerek ${ }^{182}$ genç kızlar için çok önemli olan dans; "bugünkü cemiyet dans bilmeyen bir kızı mazur görmez" diyerek uyarılmıştır. ${ }^{183}$

Âdâb-1 muâşeret kitaplarında yemek yeme usulü önemsenen bir husus olmuştur. ${ }^{184}$ Yemeğin nasıl yenilmesi gerektiği hakkında bazı eserlerde teferruata varan ayrıntılara yer verilmiştir. ${ }^{185}$ Çünkü yemek toplumsal hayatta kişinin görgüsünün anlaşılmasını sağlayan en aşikâr davranışları içermektedir. Bu muâşereti bilmeyen kişilerin mahir insanları taklit etmesi önerilmektedir. ${ }^{186}$ Değișen görgü anlayışında yemekler artık kadınlı erkekli yenmektedir. ${ }^{187}$ Bu yemeklerde bıçağın sağ, çatalın sol el ile kullanılması görgü gereği olup, ${ }^{188}$ yemekte ağzın peçete ile değil, ekmek ile temizlenmesi gerekir. ${ }^{189}$ Sert peynir, zeytin gibi bazı kahvaltılıkların elle yenileceği belirtilmişse de, 1930 sonrası yayınlarda bu anlayışın değiştiği görülmektedir. ${ }^{190}$ Et yemeklerinin nasıl yenileceği tarif edilmiştir. ${ }^{191}$ Sofradan kalkarken, "Allah'a hamd ve şükür” etmenin yanında "merci” demenin bir nezaket kaidesi olduğu belirtilmiştir. ${ }^{192}$ Toplumsal bir alan olan ibadethanelerde nasıl davranılması gerektiği ise şu şekilde ifade edilmiştir:

Her dinin mabedi, dinî müessesesi hürmete şayan bir mahallidir. Buraya girerken gayet vakur, sakin, ciddî ve hürmetkâr bulunmaya mecburuz. Orada ne yapılırsa yapılsın hepsi hürmetle seyredilmeli ve çıkarken de aynı ciddiyet gösterilmelidir. Mabet inanmış in-

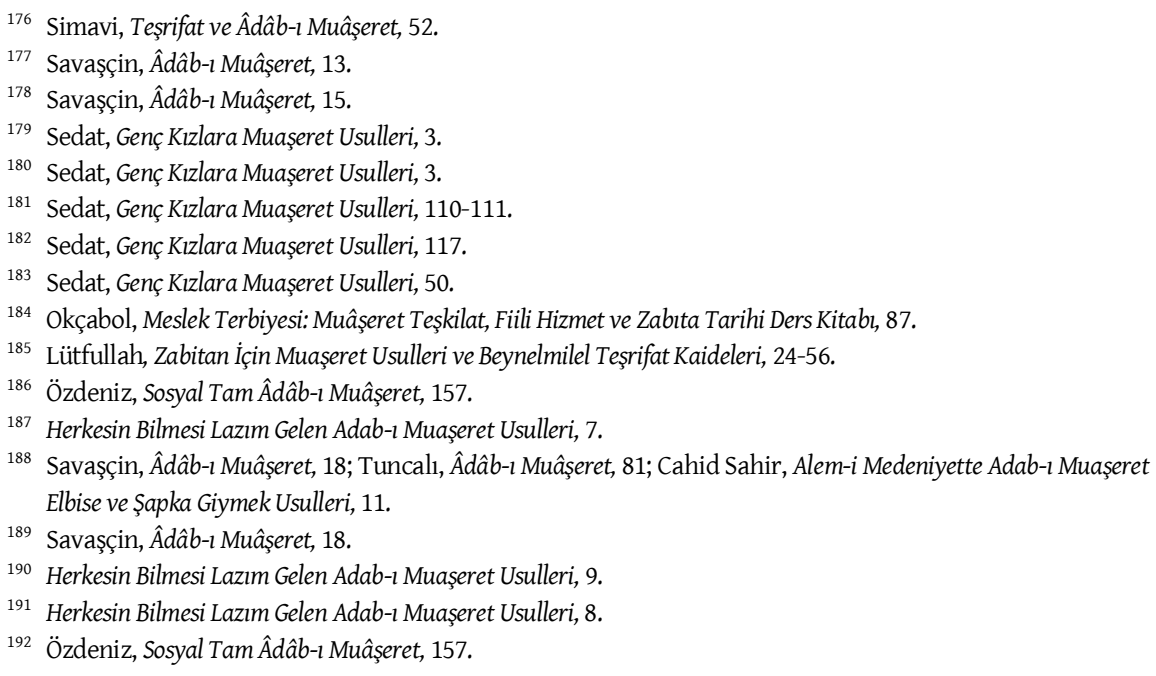


sanların Tanrı'ya karşı duydukları hislerin ifade edildiği bir yerdir. Burada en büyük muaşeret kaidesi, sükûnet, ciddiyet ve gayet terbiyeli harekettir. Burada bulunan insanların dinine, inanışlarına, fikirlerine karşı hürmetkâr bulunmak da en tabii bir neticedir. ${ }^{193}$

1940 sonrasında din eğitimi alanındaki olumlu gelişmeler âdâb-ı muaşeret kitaplarına da yansımıştır. Bu olumlu gelişmeler muhakkak ki, toplumun din bilgisi ihtiyacından ileri gelmektedir. Âdâb-ı muaşeret kitaplarında dinî konuların yer almasını da bu ihtiyaçla irtibatlandırmak mümkündür. İsmet İnönü’nün askerî okuldan sınıf arkadaşı olanÖzdeniz tarafindan bu durum şu şekilde ifade edilmiştir:

Eşref-i mahlûkat biz insanlardan karıncalara dek rızık nimetlerini ihsan eden âsümanı, ummanları; kıtaları ve bütün mükevvenatı yaratan sâni âzam kâinata cümlemizin mahmedet borçlarımız vardır. Bizler her başımız sıkıştıkça o nurlu hikmetten istimdat eder; necat, halâs ve şifayı o kibriyadan dileriz. O ilahî kuvvet ve kudrete iman etmek gerekir. Allah'tan sabah ve akşam mağfiret, niyaz ve lütfu keremine de hamdü şükürler etmeliyiz. İyi ve fena hareketlerimize göre gelecek mükâfat ve cezalara, kader ve kısmetimize de razı ve kani olmalıyı. Ve huzuru kalbe göre mazhar olarak aşamalıyız. ${ }^{194}$

\subsection{Kurumsal Konular}

Cumhuriyet öncesi âdâb-ı muâşeret konulu yayınların neşredilme sebeplerinden biri üst düzey devlet erkânına kurumsal görgü kurallarına yönelik bazı bilgilendirmelerde bulunma anlayışıdır. Bu anlayış Cumhuriyet sonrası askerlere yönelik âdâb-ı muâşeret eserlerinde de görülmektedir. Bu tür konulara yer veren en önemli yazarlardan biri Simavi'dir. Yazarın "Başmabeyincilik" gibi görevlerde bulunması bu hususlara daha fazla değinmesine sebebiyet vermiştir. ${ }^{195}$ Yine aynı zamanda asker, polis ve memurlar için hazırlanmış yayınlarda da diğerlerine oranla daha fazla kurumsal başlık yer almıştır. Bu durum, bu görevleri icra edenlerin devleti temsil etmesinden ötürü, âdâb-1 muâşereti en güzel şekilde uygulamak zorunda olmalarından ileri gelmektedir. ${ }^{196}$

Tek parti dönemi âdâb-ı muâşeret kitaplarında kurumsal konulara dair bazı başlıklar şunlardır: Millî bayramlarda devlet dairelerinde yapılacak olan programlar, ${ }^{197}$ merasimlerde giyilmesi gereken elbiseler, ${ }^{198}$ resmî dairelerde hitap ve davranış, ${ }^{199}$ bayrak - sancak ve asker merasimleri, ${ }^{200}$ şapka kullanımı, ${ }^{201}$ kartvizitler, ${ }^{202}$ davet ve hususi mektuplarda kullanılacak ifadeler, farklı mevkidekilere karşı hitap ediş. ${ }^{203}$

Kurumsal âdâb-1 muâşerete yönelik konular bu alandaki eserlerin neşredilmesinde önem arz etmiştir. İngiltere kralının yaşadığı ifade edilen şu anekdot âdâb-1

\footnotetext{
193 Tansu, Talebeye Muâşeret Usulleri, 68.

194 Özdeniz, Sosyal Tam Âdâb- 1 Muâşeret, 3.

195 Simavi, Teşrifat ve Âdâb-ı Muâşeret, 4-7.

196 Okçabol, Meslek Terbiyesi: Muâşeret Teşkilat, Fiili Hizmet ve Zabıta Tarihi Ders Kitabı, 93-95.

197 Okçabol, Meslek Terbiyesi: Muâşeret Teşkilat, Fiili Hizmet ve Zabıta Tarihi Ders Kitabı, 107.

198 Okçabol, Meslek Terbiyesi: Muâşeret Teşkilat, Fiili Hizmet ve Zabıta Tarihi Ders Kitabı, 118-121.

199 Muzaffer, Herkes İçin Modern Âdâb-ı Muâșeret, 171-174.

200 Okçabol, Meslek Terbiyesi: Muâşeret Teşkilat, Fiili Hizmet ve Zabıta Tarihi Ders Kitabı, 142-147.

201 Lütfi Simavî 1923'teki basımında bu konuya yer vermemişken, 1926'da bunu da konular arasına eklemiştir. Simavi, Teşrifat ve Âdâb-ı Muâşeret, 7-10.

${ }^{202}$ Lutfullah, Zabitan İçin Muaşeret Usulleri ve Beynelmilel Teşrifat Kaideleri, 76-95.

${ }^{203}$ Dalkılıç, Yeni Hayat Adamına Yeni Adab-ı Muaşeret, 23-83; Ongan, Talebeye Muâşeret Bilgisi, 75-77.
} 
muâşeret bilgisinin insanları nasıl zora sokabildiğini göstermesi açısından güzel bir örnektir: "Ingiltere Kral müteveffa Yedinci "Edvard" $n$ ta'âma davet ettiği Hindli bir prens bilmezlik sâikastyla sathîce el yılkamağa mahsus olan Bol içindeki suyu içtiğinden misafirini mahcup etmemek için müşârün-ileyhin de kendi önündeki bol muhteviyatın içtiği mervîdir. Cidden büyüklüğe bir numune-i imtisâl" ${ }^{\text {204 }}$ Kurumsal âdâb-1 muâşeret konularının Avrupa'da önem arz etmesinin bir diğer sebebi, din ve mevkiye göre ayrılan sınıflaşmadır. ${ }^{205}$

İnkılap kanunlarından biri olan şapka âdâb-ı muâşeret kitaplarında önemle ele alınan başlıklardandır. 1930 öncesi yayınlarda bu konu dinî temele dayandırılmaya çalışılırken, sonrası dönemde ise din ile ilgili ifadeler yer almamaktadır. Şapkanın temelini dine dayandırmak isteyen bir eserde bu konu şu şekilde dile getirilmektedir:

Bugün milyonlarca halkın giydikleri bu serpuşu bizim kabul etmememiz henüz medeniyeti idrak edemediğimizden ileri gelmişti. Dinen ve şer'an her türlü kisveyi giymeye salahattar olduğumuz halde şapkayı kabul etmemekliğimiz bir cehalettir. Hâlbuki din Muhammedî temeddün ve tefyiz hakkında birçok âyet-i kerime ve ehadis-i şerife ile Müslümanları haberdar etmişken dini kendilerine alet etmiş olan halifeler, şeyh-i İslamiler ve hocalar serpuşu kabul etmemişlerdir. Kur'an-1 Kerim'de serpuş hakkında hiçbir âyet ve hadis olmadığı halde bu hususta giyilmemesi hakkında serd edilen mütâlaalar yalnız eski kafalı, densiz hocaların fikirleridir... Ya temeddün ve terakki edeceğiz veyahut ölüp gideceğiz. ${ }^{206}$

Aynı kitabın ilerleyen kısmında yazarın şampanya, şarap vb. içkilerin hangi yemekle birlikte içileceğini ifade etmesi ise, daha önceki tavrı ile taban tabana zıt bir yaklaşımdır. ${ }^{207}$

Yayınlarda özellikle zabitan, asker ve polisin âdâb-ı muâşerete uygun davranması gerektiği vurgulanmıştır. Çünkü bu görevdekiler devleti temsil eden ve en önde yer alan kişiler olup, ${ }^{208}$ hatasının dikkat çekme ihtimali yüksektir. ${ }^{209}$ Resmî görev icra edenler arasında muâşeret kurallarına riayetin geçmişe göre iyi durumda olduğu belirtilmiş, ${ }^{210} \mathrm{bu}-$ nunla birlikte, özellikle resmî görev icra edenlerin devlet büyüklerine karşı saygı muaşeretine ihtimam göstermeleri ${ }^{211}$ ve bazı kolonya türlerini kullanmamaları gerektiği gibi hususunda uyarılarda bulunulmuştur. ${ }^{212}$ Resmî görev icra edenlerin bir diğer dikkat etmesi gereken husus; 30 Ağustos ve 29 Ekim gibi resmî zamanlarda yapılması gerekenler ${ }^{213}$ ile dinî gün ve gecelerde topluma yönelik icra edilecek faaliyetlerdir. ${ }^{214}$ Çünkü tek partili dönemde cenazelere kesinlikle siyah elbise ile gitmek gibi pek çok yeni adet uygulanır olmuştur. ${ }^{215}$

\footnotetext{
204 Simavi, Teşrifat ve Âdâb-1 Muâşeret, 26.

55 Simavi, Teşrifat ve Âdâb-ı Muâşeret, 14-15.

206 Sahir, Alem-i Medeniyette Adab-1 Muaşeret Elbise ve Şapka Giymek Usulleri, 3-4.

207 Sahir, Alem-i Medeniyette Adab-ı Muaşeret Elbise ve Şapka Giymek Usulleri, 10.

208 Özdeniz, Sosyal Tam Âdâb-ı Muâşeret, 14-15.

209 Lütfullah, Zabitan İçin Muașeret Usulleri ve Beynelmilel Teșrifat Kaideleri, 3.

210 Simavi, Teşrifat ve Âdâb-ı Muâşeret, 12-13.

${ }^{211}$ Lutfullah, Zabitan İçin Muaşeret Usulleri ve Beynelmilel Teşrifat Kaideleri, 22.

${ }^{212}$ Lutfullah, Zabitan İçin Muaşeret Usulleri ve Beynelmilel Teșrifat Kaideleri, 11.

213 Ongan, Talebeye Muâşeret Bilgisi, 54; Okçabol, Meslek Terbiyesi: Muâşeret Teşkilat, Fiili Hizmet ve Zabita Tarihi Ders Kitabı, 107, 123-127.

214 Okçabol, Meslek Terbiyesi: Muâşeret Teşkilat, Fiili Hizmet ve Zabıta Tarihi Ders Kitabı, 117.

215 Cahid Sahir -Alem-i Medeniyette Adab-1 Muaşeret Elbise ve Şapka Giymek Usulleri, 18. Benzer bir örneği Gotthard Jaschke şu şekilde vermektedir: “Genellikle kolay kolay ölmeyen dinsel gelenekler yalnız derviş
} 
Genç-yetişkin vatandaşların dikkat etmesi gereken muâşeret konularından biri okulda uyulması gereken kurallardır. ${ }^{216}$ Buna göre okula giden bir kişinin güler yüzlü, söz dinleyen, iyi ahlak sahibi ${ }^{217}$ ve okul eşyasını koruyup temiz tutma gibi davranışları sergilemesi gerekir. ${ }^{218}$ Ayrıca ailesi, dostları, yurdu ve devlet erkânının saadet-şeref, uzun bir ömür ve parlak istikbali için duada bulunmalıdır. ${ }^{219}$ Çünkü bu muâşeretin bir gereği olup, devlet kolay bir şekilde kurulmamıştır. Bu sebeple devleti kuranlar ve yönetenler muâşereti hak etmektedir. Bu anlayışa sahip olunduğu takdirde M. Kemal Atatürk ve İsmet İnönü’nün anlaşılabileceği vurgulanmıştır. ${ }^{220}$ Bir başka yayında bu durum şu şekilde ifade edilmiştir:

On beşinci yılını kutladığımız ve her an üzerine titrediğimiz şerefli ve kıymetli Cumhuriyet'imizin, unutmayalım ki, ebedî önderimiz Atatürk’ten sizlere emanettir. Bu emanete sadık kalacağımıza hepimiz onun hayatında ve önünde and içmiş bulunuyoruz. Yine Tanrı'nın biz bahtiyar kulları, Atatürk'ten sonra bizim için hakikî ve sevimli bir başkanı, onun en aziz dostu, millî şefimiz İnönü'de bulmuş, bulunuyoruz. ${ }^{221}$

İki ve daha fazla baskı yapan âdâb-ı muâşeret kitapları değişen siyasî yapıya ayak uydurmuştur. Mesela Lütfü Simavi eserinin girişinde âdâb-1 muâşeretin önemini zikrederken 1923'te neşrinde halife hazretlerinin, Cumhurreisi'nin huzuruna nasıl çıkılacağını ifade etmiş fakat 1926'daki tekrar basımında 1924'te halifelik kaldırıldığı için bu ifadelere yer verilmemiştir.

\section{Sonuç}

Bu araştırmada tek parti döneminde âdâb-1 muâşerete yönelik neşredilmiş yirmi altı eser incelenmiştir. Eserlerle ilgili değerlendirmelerde bulunulmadan önce araştırmanın problematiği, tek parti dönemi, değerler eğitimi ve âdâb-1 muâşeret hakkında genel malumatlarda bulunulmuştur. Bu bilgilendirmelerden sonra eserler bireysel, ailevî, toplumsal ve kurumsal muâşeret başlıklarına ayrılarak değerlendirilmiştir. Bu dört başlık altında; erkek-kadınların davranışları, selamlaşma usulleri, giyim-kuşam, yemek-dans-içki içme vb. adâplar hakkında alt başlıklara yer verilmiştir.

Tek parti döneminde din ve değerler eğitimine yönelik yayınlar o dönemin toplumu için büyük önem arz etmiş, günümüz araştırmacıları için ise, mezkûr yılları anlama adına veri olmuştur. Yayın değerlendirmek oldukça zor ilmî çalışmalardandır. Özellikle neşredilen yayının üzerinden seneler geçmişse, bu durum daha da zorlaşmaktadır. Bunun sebebi, neşredilen yayına hâkim olmakla birlikte dönemin siyasî, sosyal ve kültürel yönelimleriuygulamaları hakkında da malumat sahibi olmayı gerektirmektedir.

Tek parti döneminde neşredilen âdâb-1 muâşeret yayınları, mezkûr dönemde kabul edilen yeniliklerden ayrı tutulamayacağı gibi, Cumhuriyet öncesi fikir hayatı ve

tarikatlarının yasaklanması ve türbelerin kapatılmasıyla değil, aynı zamanda -aşağı yukarı bu sıralardaBatı göreneklerinin etkisiyle de zarar gördü. Böylece meselâ yas alameti olarak siyah elbise giymek, bayrakları yarıya indirmek, cenaze alaylarında bando çaldırmak, mezarları çelenk ve çiçeklerle süslemek âdet oldu." Gotthard Jaschke, Yeni Türkiye'de İslamlık, çev. Hayrettin Örs (Ankara: Bilgi Yayınevi, 1972), 41.

216 Tansu, Talebeye Muâşeret Usulleri, 5.

217 Ongan, Talebeye Muâşeret Bilgisi, 64-74.

218 Ongan, Talebeye Muâşeret Bilgisi, 55-61.

219 Tansu, Talebeye Muâşeret Usulleri, 30.

${ }^{220}$ Muzaffer, Herkes İçin Modern Âdâb-ı Muâşeret, 166-170.

221 Tansu, Talebeye Muâşeret Usulleri, 3. 
1925 öncesi muaşeret kitaplarından da bağımsız düşünülemez. Bununla birlikte, âdâb-1 muâşeret eserleri 1930 öncesi ve sonrasında içerik ve konuya yaklaşım tarzı açısından değişiklikler arz etmiştir. Cumhuriyet öncesinde muaşeret kitaplarının yazılmasının sebebini bazı yazar; sözlü kültür ve âdâb-ı muâşeret kitaplarının gündelik hayatta yaşanılan değişime ayak uyduramamasına bağlamakta, halkın bu noktada ihtiyacı bulunduğunu belirtmektedir. 1930 sonrasında basılanlar ise, kurucu iradenin benimsediği yolu halka kabul ettirmek için bir uğraş sergilediği belirtilmektedir. Bu durum, tek partili dönemde kabul edilen yeniliklerin ve muaşeret kitaplarında anlatılan davranış modellerinin yukarıdan aşağıya zorunlu bir iniş sergilediğini göstermektedir. 1930 öncesi yayınlarda dinî gerekçelendirmelere gidilirken, 1930 sonrasında bunun terk edildiği görülmektedir. Cumhuriyet sonrası âdâb-1 muâşeretin toplumun sadece belirli bir kesimine değil, geneli için bir gereklilik olduğu vurgulanmıştır. 1930 sonrası yayınlarda İslam Dininin yasakladı̆̆ı içkinin içilmesi gibi hususlar ayrıntılı bir şekilde dile getirilmiştir. Devletin koymuş olduğu kurallara uyulması gerektiği vurgulanarak örnek vatandaşın yapması gerekenler hakkında malumatlarda bulunulmuştur. Bu sebeple 1930 sonrasında neşredilenler için kurucu iradenin benimsediği yenilikleri tamamlayıc1, destekleyici mahiyette olduğunu söylemek mümkündür. 1930 öncesinde âdâb-1 muâşeret yayıncılığının matbuat merkezi İstanbul'ken, 1930 sonrasında Ankara olduğu görülmektedir. Muaşeret kitaplarında yer alan konuların çoğunluğu kadınlar hakkındadır. Kadınların yapması gereken hususlar veya onlara karşı nasıl davranılması hakkındaki konular kitaplardaki konuların çoğunluğunu teşkil etmiştir. Kadınlarla ilgili oldukça pek çok kuralın sert bir dil ile yer aldığı görülmektedir. Ayrıca genç kızlar üzerinde özellikle durulmaktadır. Bu durum, genç kızın toplum içerisindeki konumundan ileri gelebileceği gibi, yeni kurulmuş devletin kabul ettiği inkılapların benimsetilmesinde önemli görülmesinden de kaynaklanmış olabilir.

Ahlâk, muâşeret ve değerler eğitimi alanında neşredilen kitaplara Türk yayıncılık tarihi açısından bakıldığında; belirgin bir sıralamanın olduğu görülmektedir. 1800’lerin ikinci yarısında ortaya çıkan ahlak kitaplarını muâşeret yayınları onları ise, değerler eğitimi başlıklı eserler takip etmiştir. Bu açıdan ahlâk ve muâşeret kitaplarını neşredilen dönemin değerler eğitimine yönelik yayınları olarak da değerlendirmek mümkündür.

Modernleşmenin bir tezahürü olarak neşri hız kazanan âdâb-1 muâşeret kitaplarını Osmanlı son döneminden günümüze değin geçirdiği merhaleler ve içerikleri açısından ele alacak araştırmalara ihtiyaç olduğu bu araştırmada varılan en önemli sonuçlardandır. Böylece âdâb-1 muâşeret yayıncılığ açısından kültürel geçmişimizin değerlendirilmesi mümkündür.

\section{Kaynakça}

Abdullah Cevdet. Âdâb-ı Muâşeret Rehberi: Mükemmel ve Resimli. İstanbul: Yeni Matbaa, 1927.

Abdullah Cevdet. “Peyami Safa'ya Mektup”. Türk Düşüncesi 1/1 (1953), 30-31.

Ahmed Muhtar. Malumât-ı Ahlâkiye ve Medeniye'den Âdâb-ı Muâşeret Notları. İstanbul: Sanayi Mektebi Matbaası, 1926.

Ahmed Naim. Ahlâk-ı İslâmiye Esasları. İstanbul: Amedî Matbaası, 1340-1342.

Arel, S. Yemekte Muâşeret: Muhtelif Masaların Tertibi. Ankara: İdeal Matbaa, 1939.

Akşam Gazetesi. “Merhum Derviş Paşa: Cenaze Merasimi Dün İhtifalâtla Yapıldı” (19 Ocak 1932), 2. Akşam Gazetesi. “Türkçe Kur'ân” (21 Ocak 1932), 1-2. 
Akşam Gazetesi. “Türkçe Ezan” (31 Ocak 1932), 2.

Arel, Süheyla. Halkve Talebeye Âdâb-ı Muâşeret Bilgileri. Ankara: İdeal Matbaa, 1939.

Arı, Haluk Sena - Bayraktar, Kadriye. Dünden Bugüne Edep Geleneğimiz. İstanbul: Eşik Yayınları, 2011.

Arslan, Z. Şeyma - Yaşar, Fatma T. “Yükselen ‘Değer’ Kavramı Üzerine Eleştirel Bir Yaklaşım”. Değerler Eğitimi Merkezi Dergi 1 (Temmuz-Ağustos-Eylül 2007), 8-12.

Aynî, Mehmed Ali, Türk Ahlâkçıları. İstanbul: Marifet Basımevi, 1939.

Ayverdi, İlhan. Misalli Büyük Türkçe Sözlük: I (A-G). İstanbul: Kubbealtı Yayınları, 2005.

A. Lütfullah. Zabitan İçin Muâşseret Usulleri ve Beynelmilel Teşrifat Kaideleri. İstanbul: Kader Matbaası, 1932.

Başbakanllk Cumhuriyet Arşivi (BCA), Fon Kodu:30.18.1.1 Sayı:3025 Dosya:233-18 Yer No:17.84.19. Tarih:17/1/1926.

BCA, Fon No: 051.V33.000.000, Kutu No:4, Dosya No:31, Sira No:3.

Bilge, Sadık Müfit. Osmanl Devleti’nde Teşrifat ve Törenler: Tevkî̀ Abdurrahman Paşa Kânun-Nâmesi. İstanbul: Kitabevi Yayınları, 2011.

Cahit Sahir. Alem-i Medeniyette Âdâb-ı Muâşeret ve Elbise ve Şapka Giymek Usulleri. Ankara: İktisad Matbaası, 1925.

CHP Dördüncü Büyük Kurultayı Görüşmeleri Tutulgası (9-16 Mayıs 1935). Ankara: 1935.

Crıck, Ruth Elizabeth Deakin. “Farklı Kavramlar M1, Madalyonun İki değişik Yüzü Mü?”. Değerler Eğitimi Uluslararast Konferansı. 196-202. İstanbul: İstanbul İl Millî Eğitim Müdürlüğü, 2012.

Cumhuriyet Gazetesi “Diyanet İşleri Reisi İle Bir Ropürtaj: Kurân-1 Kerim ve Hutbeler Türkçe'ye Tercüme Edilecek" (10 Mayı11924), 1.

Cumhuriyet Gazetesi. “ilk Türkçe Ezan Dün Fatih’te Okundu” (31 Ocak1932), 1.

Cündioğlu, Dücane. Türkçe Kur'an ve Cumhuriyet İdeolojisi. İstanbul: Kitabevi Yayınları, 1998.

Çağrıı, Mustafa. "Edep”, Türkiye Diyanet Vakfi İslâm Ansiklopedisi. 10/414-415. İstanbul: Türkiye Diyanet Vakf1 Yayınları, 1994.

Çoştu, Kamil. “1924-1949 Yılları Arasında Din Eğitimine Yönelik Yayınlanan Eserlerin Değerlendirilmesi”. İstanbul: Marmara Üniversitesi Sosyal Bilimler Enstitüsü Din Eğitimi Bilim Dalı, Doktora Tezi, 2015.

Dalkılıç, Muhittin. Yeni Hayat Adamına Yeni Âdâb-ı Muâşeret. Suhület Kütüphanesi, İstanbul, 1932.

Dalkılıç, Süheyla Muzaffer. Öğretmenlere Yardımcı Eser: Talebeye Muâşeret Dersleri. İstanbul: İnkılâp Kitabevi, 1939.

(Dalkılıç) Süheyla Muzaffer. Herkes İçin Modern Âdâb-ı Muâşeret. İstanbul: İnkılâp Kitabevi, 1939.

Deren, Seçil, "Kültürel Batılllaşma”. Modern Türkiye'de Siyasî Düşünce: Modernleşme ve Batıcllk. 3/382389.İstanbul: İletişim Yayınları, 2002.

Eğe, Ragip Nurettin. Muâşeret Kulübü. İstanbul: Kenan Matbaası, 1944.

Ersal, Yusuf Ziyaeddin. Dinî Terbiye ve Âdâb-ı Muâşeret. Şumnu: İntibah Matbaası, 1936.

Feliha Sedat. Genç Kızlara Muâşeret Usulleri. İstanbul: Muallim Ahmed Halit Kitaphanesi, 1932.

Herkesin Bilmesi Lazım Gelen Muâşeret Usulleri. İstanbul: Resimli Ay Matbaası, 1927.

İbn Haldun. Mukaddime. çev. Turan Dursun, C. I, Ankara: Onur Yayınları, 1977.

İnal, Kemal. “Türkiye'de Geçmişten Günümüze Din Politikaları ve Eğitime Etkileri.” Değerler Eğitim Merkezi Dergisi 2 (2007), 12-17

İskender F. Sertelli. Çocuklarımıza Muâşeret Dersleri. İstanbul: Tefeyyüz Kitaphanesi, 1941-1942.

İskender F. Sertelli'nin Çocuklarımıza Muâş̧eret Dersleri Adlı Eseri Münasebetiyle Matbuatımızda İntişar Eden Tenkidler. İstanbul: Tefeyyüz Kitabevi, 1941.

Jaschke, Gotthard. Yeni Türkiye'de İslamlık. çev. Hayrettin Örs, Ankara: Bilgi Yayınevi, 197.

Karay, Refik Halit. "Eski ve Yeni Yılbaşı Geceleri”. Panoroma 1/9 (Ocak 1955), 4-5.

Kaymakcan, Recep. “Gençlerin Dinî Değerlere Bakışı: Türkiye ve Avrupa Karşılaştırması”. Değerler Eğitimi Uluslararası Konferansı. 13-30. İstanbul: İstanbul İl Millî Eğitim Müdürlüğü, 2012. 
Meriç, Nevin. Âdâb-ı Muâşeret: Osmanl'da Gündelik Hayatın Değişimi (1894-1927). İstanbul: Kapı Yayınları, 2007.

Lütfi Simavi. Teşrifat ve Âdâb-l Muâş̧eret. İstanbul: Marifet Matbaası, 1926.

Süheyla Muzaffer. Yemek ve Muaşeret Bilgileri. İstanbul: y.y., 1943.

Okçabol, Derviş. Meslek Terbiyesi: Muâşseret Teşkilat, Fiili Hizmet ve Zabıta Tarihi Ders Kitabı. Ankara: Ankara Polis Enstitüsü Neşriyatı, 1940.

Ongan, Hidayet. Talebeye Muâşeret Bilgisi. İstanbul: Ahmet Sait Basımevi, 1938.

Ömer Lütfü. Âdâb-ı Muâşeret: Hayat-ı İçtimaiye. Harbiye Mektebi Matbaası, 1930.

Öz, Ayhan. "Heyet-i İlmiye Toplantıları ve Millî Eğitim Şûralarında Din Eğitimi”. Sakarya Üniversitesi İlahiyat Fakültesi Dergisi 16/29 (2014), 129-156.

Özdeniz, Bahri. Sosyal Tam Âdâb-ı Muâşeret. İstanbul: İkbal Kitabevi, 1942.

Öznal, Erdoğan. Protokol Görgü- Nezaket Kuralları. Ankara: Genelkurmay Başkanlı̆̆ı Yayınları, 1992.

Revel, Jacques. “Adabı Muaşeretten Yararlanma Yolları”. Özel Hayatın Tarihi: 3. çev. Devrim Çetinkasap. 231-289. İstanbul: Yapı Kredi Yayınları, 2007.

Savaşçin, Hüsnü. Âdâb-1 Muâşeret. Kayseri: Vilayet Matbaası, 1938.

Sevinç, Nilgün. Protokol Bilgisi. Ankara: Detay Yayınları, 2004.

Saffeti Ziya. Âdâb-ı Muâşseret Hasbihalleri. Ankara: Türk Ocakları Merkez Heyeti Matbaası, 1927.

Şahin, Ayhan. Kamu İdarelerinde Protokol Kuralları. İstanbul: Yeni Yüzyıl Yayınları, 2011.

Şen, Hasan. Kemalist Modernleşme ve İslamcı Gelenek. Ankara: Kadim Yayınları, 2012.

Tansu, Samih Nafiz. Talebeye Muâşeret Usulleri. İstanbul: Kanaat Kitabevi, 1939.

Tuncalı, Sezai. Âdâb-ı Muâseret. H. O. Basımevi, İstanbul, 1940.

Ural, Tülin. “Tek Parti Döneminde Basılmış Adab-1 Muaşeret Kitaplar1”. Müteferrika:Kitabiyat Dergisi 33 (2008), 243-274.

Uyar, Hakkı. Tek Parti Dönemi ve Cumhuriyet Halk Partisi. İstanbul: Boyut Kitapları, 1998.

Uyar, Hakkı. “Çarşaf, Peçe ve Kafes Üzerine Bazı Notlar”. Toplumsal Tarih Dergisi 33 (Eylül 1996), 6-11.

Vakit Gazetesi. “Diyanet İşleri Reisi ile Bir Ropörtaj: Kurân-1 Kerim'in Türkçesi” (12 Mayıs 1926), 1.

Vasıf Necdet. Muaşeret Yolları. Bursa: Kardeş Matbaası, 1926.

Yaşar, Tunç Fatma. Alafranga Halleri: Geç Osmanlida Âdâb-ı Muâşeret. İstanbul: Küre Yayınları, 2016.

Yaşar, Tunç Fatma. “Geç Dönem Osmanlı Âdâb-1 Muaşeret Literatürü”. Toplumsal Tarih Dergisi 231 (Mart 2013), 52-59.

Yaşar, Tunç Fatma. “Geç Dönem Osmanlı Kız Mekteplerinde Fennî Ev İdaresi Eğitimi: Müfredat ve Ders Kitaplar1”. Türkiyat Mecmuast - Journal of Turkology 29/2 (2019), 591-620. 